\title{
THE MARKET POWER OF GLOBAL SCIENTIFIC PUBLISHING COMPANIES IN THE AGE OF GLOBALIZATION. AN ANALYSIS BASED ON THE OCLC WORLDCAT
}

\begin{abstract}
Arno Tausch
This article evaluates tendencies and trends of the global academic publishing industry, vital for any reasonable long-term publication strategy planning in research. Such analyses are made possible today by the OCLC Worldcat. Our multivariate attempt, combining Worldcat global library circulation figures of publisher companies with results from earlier publisher ranking studies, is based on factor analysis of 32 variables, and our promax factor analytical model establishes that there are eight factors of global publisher impact, explaining almost $86 \%$ of total variance:

1. overall global standing of the company

2. company as a factor on the market

3. company impact on the global political and economic debate

4. successfully distributing best-sellers

5. impact on the scholarly community

6. successfully distributing production to more than 50 global Worldcat libraries

7. output during the last five years

8. outstanding academic quality

Of the 51 companies with complete data under investigation here, the following companies are classified in the upper half: Oxford University Press; Springer; Cambridge University Press; Routledge; World Bank; Princeton University Press; Elsevier; CRC Press; University of Chicago Press; University of California Press; Palgrave Macmillan; MIT Press; Yale University Press; University of North Carolina Press; De Gruyter; Wiley-Blackwell; Kluwer Academic Publishers; University of Pennsylvania Press; Johns Hopkins University Press; Brill; Nova Science Publishers; University of Illinois Press; Duke University Press; University of Washington Press; and Edward Elgar. Scientists, wanting to get global audiences, are well advised to publish with those companies; and journal editors, wanting to get a global distribution for their journals, are equally well advised to cooperate with them.
\end{abstract}

Keywords: role of economics; role of economists; history of thought: individuals; entertainment; media (performing arts, visual arts, broadcasting, publishing).

Journal of Globalization Studies, Vol. 9 No. 2, November 2018 63-91

DOI: 10.30884/jogs/2018.02.05 


\section{Introduction}

The global library network OCLC Worldcat was founded in 1967 at the Ohio College Library Center as a federation of just only 54 Ohio colleges while today it already brings together 16,548 libraries in 124 countries. Thus, it is by far the largest library network in the world and it offers unique opportunities for academic 'marketing research' in all disciplines, including globalization studies. Its full version, OCLC First Search, is an indispensable tool for academic research, analysis and academic strategy planning. But even open access versions of the Worldcat already contain vital information for the producers and consumers of global social science, including globalization studies, alike.

\section{OCLC Worlcat - a Necessary Compass in the World of Globalized Social Science}

Our article attempts to provide some basic ideas about the globalized publishing industry, the tool to transport globally academic findings, and it does so with the help of OCLC tools, like OCLC First Search, but also the open access portals OCLC Classify, OCLC advanced search, and TE PUNA (the New Zealand Library catalogue) on OCLC, which already offers freely enormous opportunities for the global research community (https://tepuna.on.Worldcat.org/discovery).

The basic idea of the project, which was founded by Frederick Kilgour (19142006), was to unite the knowledge of humanity available in libraries. Today, the catalog ranges from the University of Alaska in Fairbanks, Alaska to the Universidad de Concepción in Southern Chile, and from Tromsö University in Northern Norway to the University of Cape Town, South Africa, and is now expanding into the Asia-Pacific region as well into the Middle East, and Worldcat now integrates major libraries in the BRICS countries. It will be difficult to find a university library from one of the top 100 universities in the world, classified under the Shanghai University Ranking ${ }^{1}$ System or the SCIMAGO SIR University and Research Institute ranking, ${ }^{2}$ based on SCOPUS indexed publications ${ }^{3}$ that is not a member of the OCLC Woldcat. Virtually all major libraries in Western Europe are also members of the OCLC Worldcat today, for example 428 in Germany, 1,212 in France and 261 in Italy.

Can any reputable academic research library now afford to remain outside this vast global network? With 389 million entries in 491 languages, with over 40 million daily accesses worldwide? Reasons for membership are manifold: to make the knowledge of teachers and students stored at local libraries globally more visible, provide scientists and students with an important navigation aid in the international science market et cetera.

The OCLC Worldcat - Designing Scientific Publication Strategy and Assessing Global Scientific Impact on Your Smartphone or at a Mouse Click

Even on a smartphone, and even the open access the New Zealand TE PUNA on Worldcat offers enormous research opportunities, for example the ranking of all the 1988 global journals by global library presence corresponding to the keyword 'globalization' (see Fig. 1). 
"TE PUINA on Worldcat"

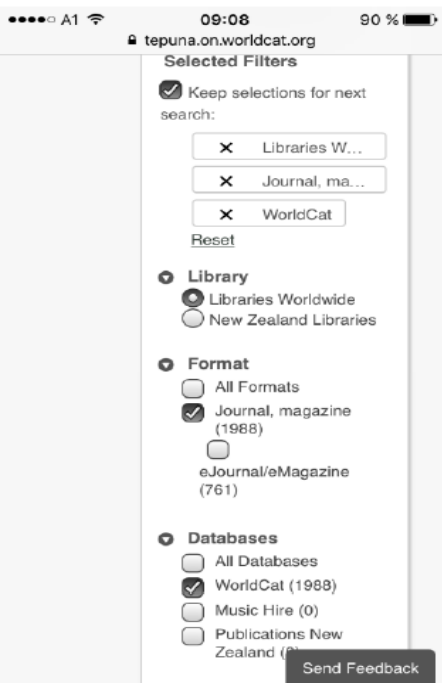

Fig. 1. Ranking the global library presence of globalization-related scientific journals with the open-access Worldcat version available from the New Zealand catalogue TE PUNA on a smartphone

In Fig. 2, we show the global library outreach of the journal best corresponding to the profile of the present journal, the 'Journal of Globalization Studies'. Pure and simple, the list of global libraries cataloguing this competing journal (the 'Journal of Globalization and Development' published by Berkeley Electronic Press), ${ }^{4}$ shows the current maximum market for any competing globalization studies journal, and this market consists of only 454 libraries around the world.

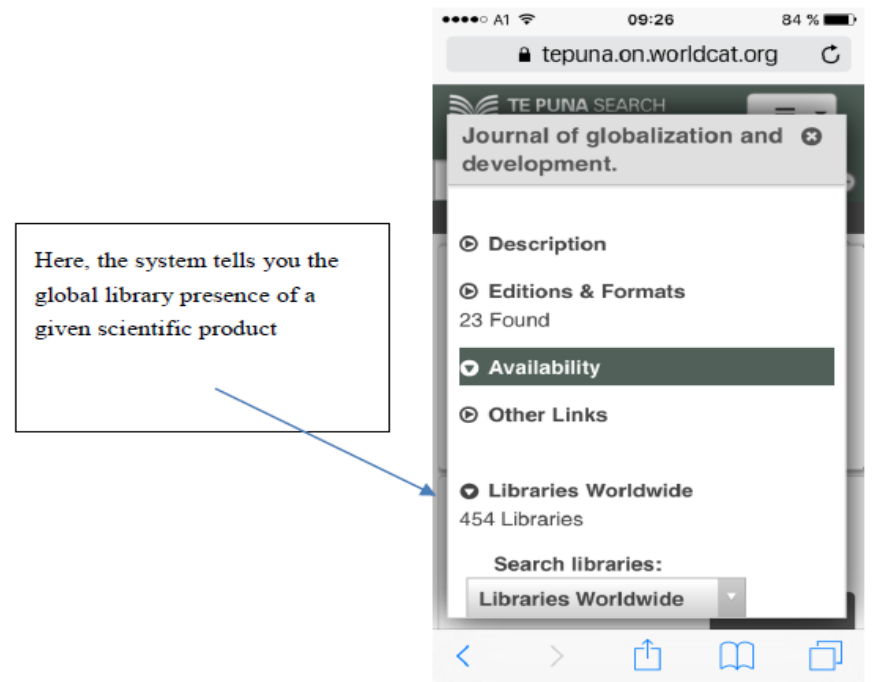

Fig. 2. The library impact of the globalization studies journal with the highest global library impact 
The publishers and the editors of the present journal now can compare their own global distribution figures with those of the Berkeley 'Journal of Globalization and Development', and target the directors of the libraries, already subscribed to 'Journal of Globalization and Development' and not yet subscribed to the 'Journal of Globalization Studies' with subscription offers.

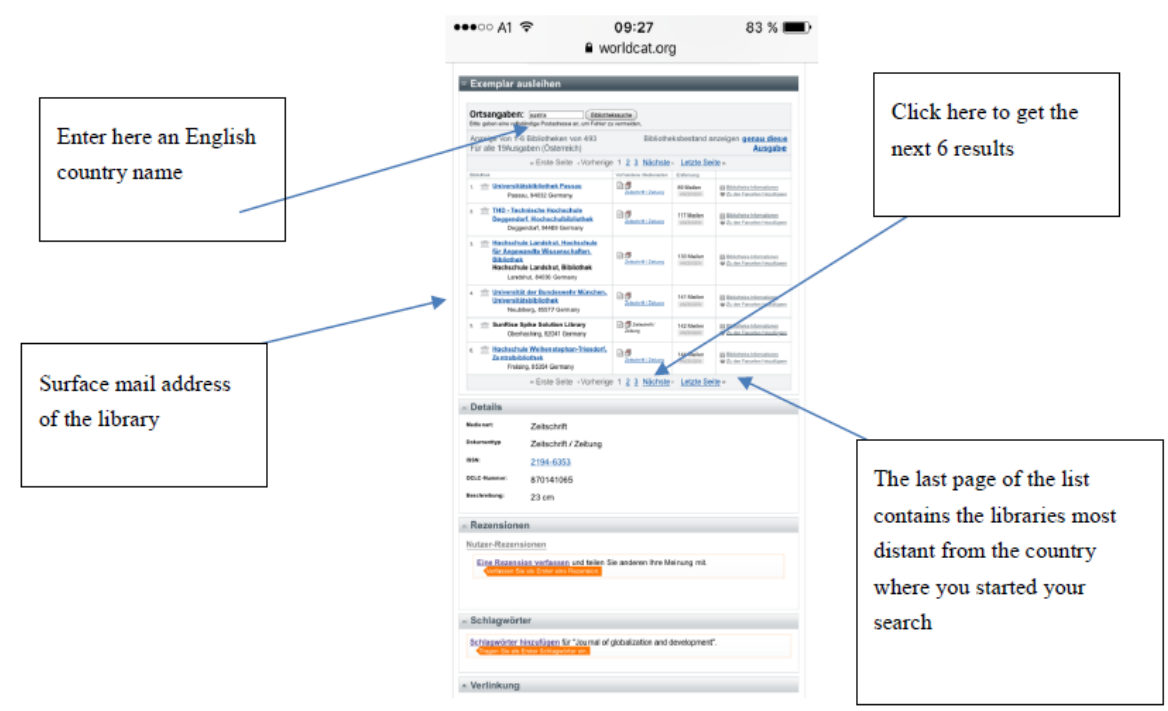

Fig. 3. The address lists of libraries subscribed to a competing journal in the field of globalization studies on a smartphone

Further questions that can be answered with the OCLC Worldcat First Search are, for example: how efficiently does your country's or your city's or your University's science reach a geographically extremely disperse audience? OCLC Classify even answers the understandable query by any scientific author whether his or publications are available at Harvard and Yale, Oxford and Cambridge, at the Nehru University in Delhi, at the Ben Gurion University in Be'er Sheva, Israel, and in Sao Paulo? And in Morocco and Jordan, in Ghana, in Ulan Bator and in Beijing? In Sydney and in Singapore? Malaysia or Botswana? And all this is made visible today with a single mouse click on your computer or with the touch of your thumb on your smartphone! Here, show to our readers the readership of Piketty's classic (2014) in the geographical region of Central and East Asia: 


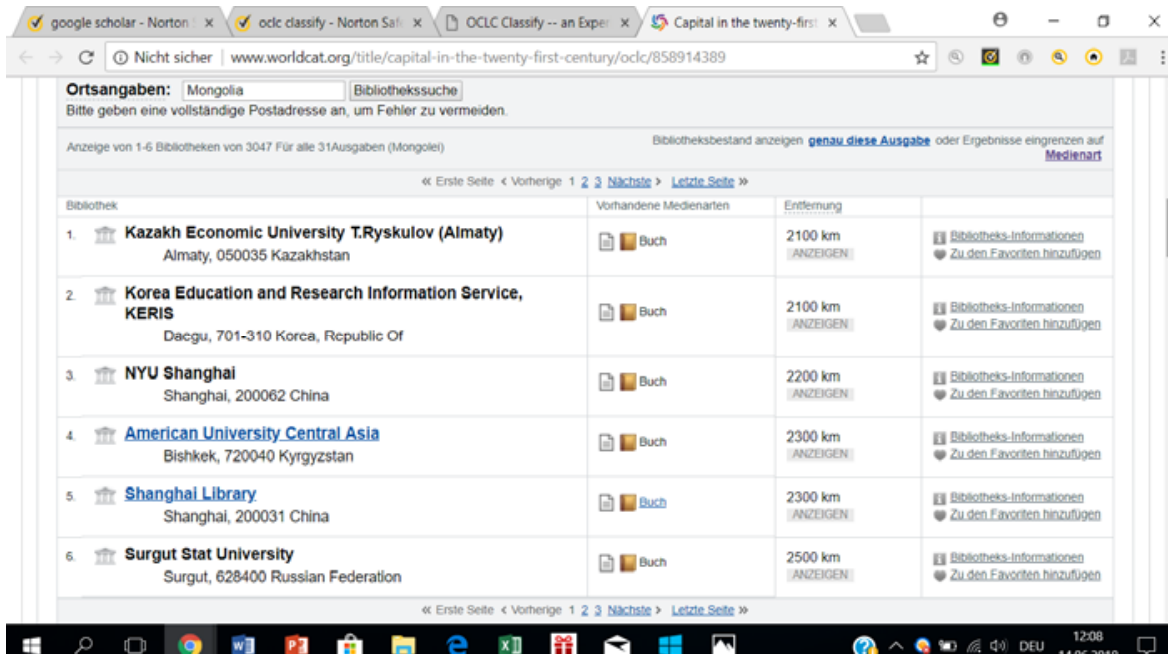

Fig. 4. Searching for global library presence with the Open Access Version OCLC Classify: the presence of Piketty's classic (Piketty 2014) in Central Asia

Why you should phone your chief librarian today, telling him/her that your library must become immediately a member of the OCLC Worldcat system

So, what are the general benefits of OCLC Worldcat?

- Access to data on library holdings and services with 2 billion holdings;

- Library-centered research that draws members' attention to important topics and trends, including access to reports from OCLC Research.

In the following I present what are OCLC Worldcat's main application areas for scientific strategy development in a global world market for science products today:

1) Determination of the global library impact of individual scientists, but also institutes, universities, the provision of objective criteria for the assessment of the effect of book or journal publications.

2) Book Publication Impact Monitoring, also for impact studies of books, studies and journals written at your research center on a global level and in individual regions of the world, even over time.

3) Quick selection of the most suitable publishers for future academic book publications which have the highest global readership for specific topics over the last few years and which have made the works of researchers available to a maximum of libraries worldwide.

4) Academic publishers based in your country would be able to search specifically for global libraries that already represent a true comparable market for products produced at your company in comparison to existing market leaders.

5) Which libraries worldwide are buying products from, say, Austrian, Australian, Brazilian, Chinese, Russian et cetera publishers? How does it compare to the distribution figures for competing publishers with a similar profile from, say, Scandinavia, the Netherlands, etc., discipline for discipline?

The harsh realities of global academic publishing

Worldcat is not only your publisher's marketing department's dream, and a powerful tool of scientific impact research, suitable for Vice-Deans, Vice-Presidents of Universi- 
ties etc. OCLC Worldcat tells us also a lot about the harsh realities of the globalization of science today.

We can estimate from the OCLC data that of the more than 300 million books held in global libraries, more than 120 million books were published in English, 43 million in German, and around 31 million in French. Especially German as a scientific language is tremendously on the retreat over the last decades. Of the 20.8 million books published in the last five years, 45 per cent were published in English, and in the field of political science, for example, this share was even 55 per cent. The concentration of the publication process on a global scale is enormous. In the field of political science alone, 13 leading publishers with an output of more than 400 political science books during the last five years published none the less than 38 per cent of the 1.7 million English language political science titles during the last five years.

Table 1 summarizes this global concentration process and the global maximum library outreach of these companies.

Table 1

The global main publishers of political science during the last five years

\begin{tabular}{|l|c|c|c|c|c|}
\hline \multicolumn{1}{|c|}{ Publisher } & $\begin{array}{c}\text { OCLC WC } \\
\text { number of po- } \\
\text { litical science } \\
\text { books pub- } \\
\text { lished in the } \\
\text { last 5 years }\end{array}$ & $\begin{array}{c}\text { Political sci- } \\
\text { ence book (last } \\
5 \text { years) with } \\
\text { the highest } \\
\text { global library } \\
\text { circulation rate }\end{array}$ & $\begin{array}{c}\text { Political science } \\
\text { book (last } \\
5 \text { years) with } \\
\text { the 50 highest } \\
\text { global library } \\
\text { circulation rate }\end{array}$ & $\begin{array}{c}\text { Continuity of } \\
\text { performance - } \\
\text { top 50 political } \\
\text { science books } \\
\text { last 5 years) }\end{array}$ & $\begin{array}{c}\text { Share of politi- } \\
\text { cal science } \\
\text { titles per } \\
\text { total titles, } \\
\text { last 5 years }\end{array}$ \\
\hline Routledge & 14,552 & 681 & 224 & 32.89 & 5.25 \\
\hline $\begin{array}{l}\text { Palgrave } \\
\text { Macmillan }\end{array}$ & 10,949 & 1,310 & 166 & 12.67 & 9.08 \\
\hline Springer & 10,083 & 692 & 305 & 44.08 & 1.97 \\
\hline $\begin{array}{l}\text { Oxford Univer- } \\
\text { sity Press }\end{array}$ & 6,759 & 873 & 397 & 45.48 & 5.16 \\
\hline $\begin{array}{l}\text { Cambridge Uni- } \\
\text { versity Press }\end{array}$ & 5,236 & 807 & 230 & 28.50 & 5.20 \\
\hline $\begin{array}{l}\text { Princeton Uni- } \\
\text { versity Press }\end{array}$ & 1,405 & 1,321 & 622 & 47.09 & 6.29 \\
\hline Brill & 838 & 846 & 85 & 10.05 & 1.89 \\
\hline Edward Elgar & 813 & 236 & 54 & 22.88 & 4.22 \\
\hline $\begin{array}{l}\text { University of } \\
\text { Pennsylvania } \\
\text { Press }\end{array}$ & 672 & 1,297 & 427 & 32.92 & 8.74 \\
\hline De Gruyter & 582 & 1,283 & 42 & 3.27 & 0.77 \\
\hline $\begin{array}{l}\text { University of } \\
\text { Chicago Press }\end{array}$ & 484 & 624 & 141 & 22.60 & 3.95 \\
\hline $\begin{array}{l}\text { Yale University } \\
\text { Press }\end{array}$ & 408 & 832 & 186 & 22.36 & 3.09 \\
\hline $\begin{array}{l}\text { Nova Science } \\
\text { Publishers }\end{array}$ & 402 & 695 & 458 & 65.90 & 2.43 \\
\hline
\end{tabular}

Source: calculated with https://tepuna.on.Worldcat.org/discovery - books only.

We also have to emphasize that authors publishing only in Russian, German or in other languages other than English find it much harder to reach global markets than authors, who presented their works in English in the first place. A good work published with a leading Russian or German language book company will often reach only 40, 50, 
or 100 global libraries as a maximum. But even high-quality English language books might find it sometimes hard to find an appropriate library outreach of more than 50 libraries, especially if the price of a book is high or if your publisher's marketing facilities are not so well developed. A global social scientific star, sociologist Prof. Ronald T. Inglehart, reached with an American University Press publisher (Abramson and Inglehart 2009) 1,235 global libraries, while with a renown Canadian publisher (Inglehart 2002) only global 175 libraries. It would be sheer nonsense to believe that book number 1 by colleague Inglehart is seven times 'better' or 'more important' than book number 2, because it achieved seven times more library holdings.

If even a flagship foreign language publication like the Russian language 'Mirovaia ekonomika i mezhdunarodnye otnosheniia', which was studied in the days of the Cold War by hundreds of Western security and defense experts, only makes it to 125 global libraries, then it is not scientific quality or political importance, which matter, but that the journal is a foreign language product on the Anglo-American dominated market, pure and simple. Seen in such away, a library outreach of 100 libraries for a scientific publication published in a country like Russia is not a defeat but a victory. Still, the publishers of 'Mirovaia ekonomika' can compare the holdings of their journal with the maximum circulation of any Russian language journal in the world today, the 'Obshchestvo: Politika, ekonomika, pravo = Society: politics, economics, law.' published in Krasnodar by the LLC Publishing House 'HORS', [according to OCLC First Search at 676 global libraries]. These 676 global libraries can safely be assumed to constitute the maximum library outreach of any social science publication published in the language of Alexander Sergeyevich Pushkin.

As we show in the following, there are severe international market constraints even for English language academic publications, printed at any of the University Presses of the world today.

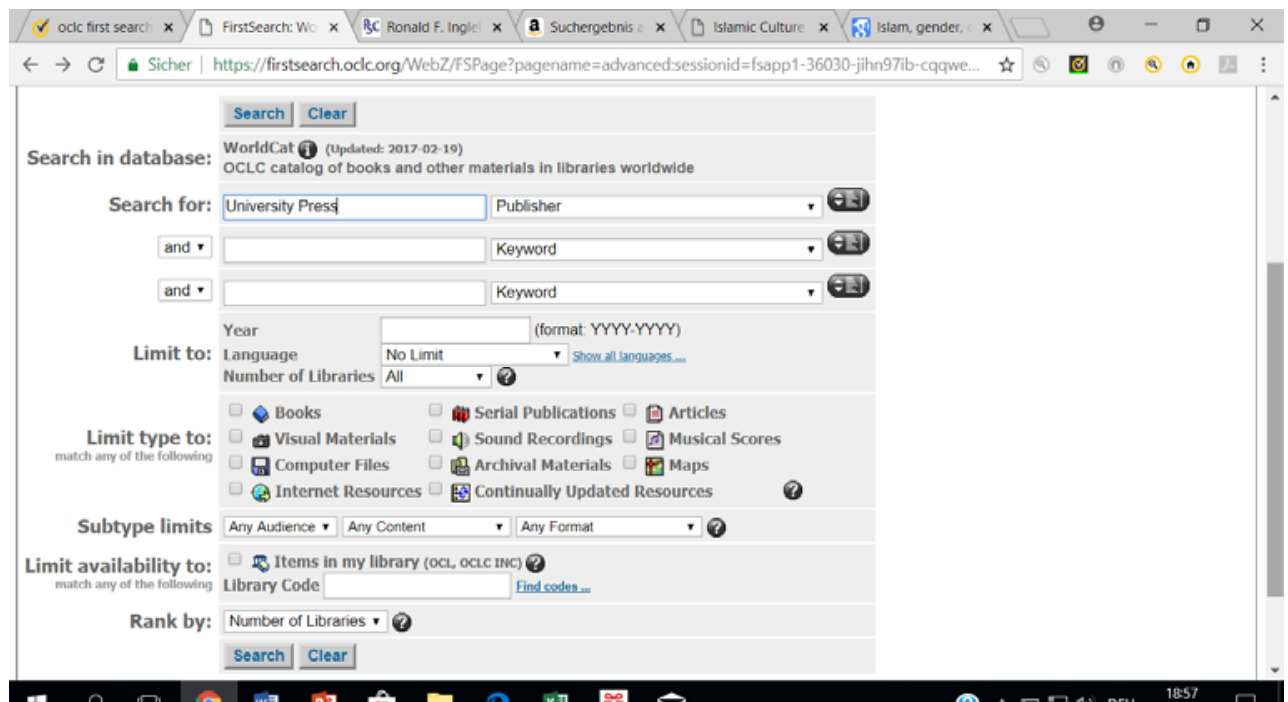

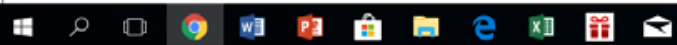

Fig. 5. Searching for the University Press publication with the highest global outreach on OCLC First Search 
Only 1.93 per cent of the global University Press publications of the last five years reached more than 500 global libraries, and the record holder was not unsurprisingly the work by Piketty (2014). Piketty's global audience is a good indication of the maximum market of an English language book or journal on globalization.

\section{Libcitation - a New Scientific Tool to Assess Academic Marketing Success, Based on OCLC Worldcat Data}

Usual attempts in the field of bibliometry are centered on the concept of citation patterns, while the globalization of book production has seldom been studied in its totality. And yet, it is evident that in the fields of social sciences and the humanities, where book production is still considered to be a major channel of scientific output, such attempts must and should be made.

The present article attempts then to apply so-called Libcitation measurement techniques, recently developed in the context of the Excellence in Research for Australia program. Libcitation, a term first coined in a published article by Howard D. White et al., is a measure designed to estimate the global or also regional presence of authors, universities, research institutes or an entire scientific community on different markets:

[The] [...] measure introduced here is called the Libcitation. [...] It is made on books. For a particular book (i.e., edition of a title), it increases by 1 every time a different library reports acquiring that book in a national or an international union catalog. Readers are invited to think of union catalogs in a new way: as 'librarians' citation indexes.' The idea is that, when librarians commit scarce resources to acquiring and cataloging a book, they are in their own fashion citing it, just as scholars do when they refer to it in new works of their own; both are engaged in bibliographic speech acts. As these 'librarians' citations' accrue differentially to different books in union catalogs, we gain data for a new indicator. The number of libraries holding a book at a given time constitutes its Libcitation count.

Counting the presence of author's or even publishing companies' outputs in Union catalogues is a straightforward methodology to ascertain something like the 'real market weight'. White et al. point to the fact that:

Whereas traditional citation counts reflect judgments by authors' peers on publications useful to them, Libcitation counts reflect judgments by librarians on the usefulness of publications for their various audiences of readers. The Libcitation measure thus resembles a citation impact measure in discriminating values of publications on a defined ground. It rewards authors whose books (or other publications) are seen by librarians as having relatively wide appeal. A book's absolute appeal can be determined simply by counting how many libraries hold it, but it can also be gauged in relation to other books in its subject class.

Since there is a very close working relationship between scholarly and teaching activities and the respective libraries at Universities around the world, we can only emphasize the point made by White et al.

We anticipate the cry, 'But librarians aren't like citers; they don't know anything!' It is true that librarians rarely make new knowledge claims and are seldom considered the peers of the scientists and scholars who do. Neverthe- 
less, what they acquire and record in union catalogs involves the wide cultural literacy that is at the heart of librarianship. On the service front, Libcitations reflect librarians' knowledge of audiences - their approximate sizes, the topics that interest them, their degrees of expertise, and their localized concerns (e.g., what is important to Australians as opposed to non-Australians). On the book front, Libcitations reflect what librarians know about the prestige of publishers, the opinions of reviewers, and the reputations of authors. The latter may be colored by, for example, authors' academic affiliations, previous sales, prizes, awards, distinguished appointments, mass media coverage, Web presence, and citedness. All of these are signals of what readers are likely to want, and librarians must be attuned to them. A book's Libcitation count is thus its holdings count in a union catalog seen in a different light. Holdings counts are an unobtrusive measure that cannot be altered by researchers changing their behavior. They cannot easily be 'gamed,' assuming current standards of record keeping. They may change over time, but data on them already have accumulated for many years in several union catalogs, and millions of them are by now quite stable.

Even if we could theoretically assume that 'non-scientific, non-market pressure' by scientists could influence the book ordering policies of a few departments or libraries, a strong position of a given scientist or journal or publication in the library holdings of tens of thousands of libraries around the globe cannot be the product of coincidence or collusive pressure alone. Librarians, first of all, listen to the ordering wishes from the respective faculties and academic departments at their institutions, secondly, they, for themselves, also evaluate the current literature reviews and even international press articles to round up their opinions on the developments of a given discipline and their implications for catalogue development.

Zuccala et al. (2015) already established that there is a close correlation between Scopus-Indexed publications and global library presence in Worldcat. Our chosen indicators take into account the all-too-well-known fact that the global audiences in the social sciences are hardly known. Usual attempts at citation-based rankings try to measure the standing of scientists with other members of the science community, and hardly with the global public at large.

At the same time, this way of measurement is much more market-decision based than analyses based on citation patterns, which tell us hardly anything about the geographical aspects of the world distribution of knowledge. A librarian or a library community, in addition, has to spend scarce resources on each purchased book, and their decision to buy an academic title, often at the price of $70 \$, 80 \$$, or more, is a real decision to devote scarce resources.

Since publishers, with justification, regard global and geographically broken-down sales figures as a well-guarded secret, available only to the publisher(s) and their author(s), and since the usual alternative - available bestseller rankings from Internet bookstores - are but a very unreliable indicator of the development of the global publishing market, and change frequently over time, we are practically left to work only with this relatively new methodology. We round up our methodology by the yearly download figures of the respective articles on the analyzed companies contained in Wikipedia. 


\title{
Rankings of Book Publishers
}

In the past, there were several attempts to rank book publishers by qualitative methods. The Dutch Research Consortium SENSE ${ }^{5}$ used five categories. This ranking was based on the subjective opinion of the scientists working for this important consortium in the field of environmental studies in the Netherlands:

\section{I refereed book publications:}

A: Refereed book publications published by the world top of publishers;

B: Refereed book publications published by the world's semi-top of publishers;

C: Refereed book publications published by other publishers;

II non-refereed book publications

D: published for an academic public (professional publications);

E: mainly published for a non-academic (general) public.

Their ranking reached the following conclusion about the global top players in the field of global academic publishing:

\author{
A-publishers (a few top-notch international publishers) \\ Cambridge University Press \\ Columbia University Press \\ Harvard University Press \\ John's Hopkins University Press \\ MIT Press Cambridge, Massachusetts \\ Oxford University Press \\ Princeton University Press \\ Stanford University Press \\ University of Chicago Press \\ Yale University Press
}

An influential study by the Universidad de Granada ${ }^{6}$ was based on the Clarivate Analytics 'Book Citation Index ${ }^{7}$ and ranked Springer, Palgrave Macmillan, Routledge, Cambridge University Press, Elsevier, Nova Science Publishers, Edward Elgar, Information Age Publishing, Princeton University Press and University of California Press as the global leading academic publishers.

The University of Groningen in the Netherlands, one of the world's 100 top Universities, now runs a system by which researchers and students from around the world can find complete information on the book and journal publishing companies, chosen by the staff of one of the world's leading Universities for their scientific publications. ${ }^{8}$ This complete documentation system, currently listing more than 233,000 scientific publications, informs us for example that in view of the list reproduced in Table 1 of this essay, there were 657 Groningen publications with Routledge, 170 publications with Palgrave, but 2,120 publications with Springer and 48 publications with Nova Science Publishers, the last of the mentioned 13 companies in our Table 1. 5,903 publications by the Groningen University researchers took place in the context of any University Press around the world; and one essay, van der Vliet (2008), was published with Uchitel, the publishing company of the present journal. 


\section{Methods for the Empirical Analysis of Publisher Market Power}

Now, this essay builds on a bibliometric analysis of 57 major book publishing companies, for which there are complete available data for both the above-mentioned SENSE Index and the book-citation related study by Torres-Salinas et al., 2012, 2013, and 2014a, 2014b, referred to here as the 'Granada studies' in bibliometrics (Tausch 2015a).

With the data, now available from OCLC, the author calculated or collected the following variables in addition to the comprehensive Tausch, 2015a study:

- $\%$ of titles with an OCLC Worldcat circulation between 50 and 500 global libraries ${ }^{9}$

- $\%$ of titles with an OCLC Worldcat circulation of less than 50 global libraries ${ }^{10}$

- $\%$ of titles with an OCLC Worldcat circulation of more than 500 global libraries ${ }^{11}$

- book (last 5 years) with the 50th highest OCLC Worldcat circulation rate ${ }^{12}$

- book (last 5 years) with the highest OCLC Worldcat circulation rate ${ }^{13}$

- continuity of performance $-50^{\text {th }}$ best circulated book compared to the top circulated book (last 5 years) ${ }^{14}$

- OCLC WC number of book titles published in the last 5 years (TE PUNA on Worldcat $^{15}$

- Recent titles with more than 50 OCLC Worldcat circulation ${ }^{16}$

- Recent titles with more than 500 OCLC Worldcat circulation ${ }^{17}$

- total number of recent titles (not just books; OCLC First Search) ${ }^{18}$

- Wikipedia monthly downloads of articles featuring the company over last year (English sites only $)^{19}$

In view of the importance of the social media and the Internet for company reputation today, we also included data about Wikipedia monthly downloads of articles featuring the company over last year. These data also reflect, as the rest of our indicators, the element of the standing of a company with the general publics and not just the academic community alone.

The Tausch, 2015a variables, again used in the present study were:

Publishing the results of science

- Quantity Indicator - number of books and book chapters in the Clarivate Analytics (formerly Thomson-Reuters) Book Citation Index ${ }^{20}$

- Citations of books and book chapters in the Clarivate Analytics (formerly Thomson-Reuters) Book Citation Index ${ }^{21}$

- Harvard Library number of titles (books only) 2 $^{22}$

- number of references about the company in books - Questia ${ }^{23}$

Citations, impact and standing in the academic community

- average citations - books and book chapters ${ }^{24}$

- $\quad$ standard deviation citations books and book chapters ${ }^{25}$

- Sense Quality Indicator for multivariate analysis ${ }^{26}$

- Harvard HOLLIS ratio of books checked out per total holdings (books only $)^{27}$

- average citations - books in the Clarivate Analytics (formerly ThomsonReuters) book citation inde $x^{28}$

- number of references about the company in scholarly journals - Questia ${ }^{29}$

Market penetration in industrialized Western countries

- Japanese NACSIS top library outreach (books only) ${ }^{30}$

- Japanese NACSIS 200th library outreach (books only) ${ }^{31}$ 
- $\quad$ Swedish LIBRIS top library outreach ${ }^{32}$

- Swedish LIBRIS 50th library outreach ${ }^{33}$

Attention given to the books by the international decision makers

- Items in ECLAS catalogue of the European Union in Brussels ${ }^{34}$

- Items in World Bank/IMF JOLIS library catalogue Washington (books only) ${ }^{35}$

Market penetration in developing countries

- Items in the IndCat (India) Union catalog ${ }^{36}$

Attention given to the books in the international media

- number of references about the company in magazines - Questia ${ }^{37}$

- number of references about the company in newspapers - Questia ${ }^{38}$

It was expected that all quality and quantity criteria correlate very highly with each other. For that reason, the author chose the factor analytical model of promax factor analysis (see Tausch 2015b). The factor analytical results were also used to arrive at a combined index of publisher market power. This index combines the factor scores for each derived factor, weighted by the Eigenvalues (see, for an extensive debate about these procedures, Tausch 2015b).

\section{Results}

Table 2, Table 3, Table 4, and Table 5 are reprinted here for the specialists, and they should describe the most important aspects of our factor analytical model of publisher market power in a globalized world of science.

Table 2

The multivariate promax factor model of publisher market power - variance explained

\begin{tabular}{|l|c|}
\hline & Variance explained \\
\hline Wikipedia monthly downloads, English, last year & 0.643 \\
\hline OCLC WC number of books published in the last 5 years & 0.971 \\
\hline book (last 5 years) with the highest global library circulation rate & 0.735 \\
\hline book (last 5 years) with the 50th highest global library circulation rate & 0.958 \\
\hline continuity of performance - top 50 books (last 5 years) & 0.807 \\
\hline $\begin{array}{l}\text { Quantity Indicator - number of books and book chapters in the Clari- } \\
\text { vate Analytics (formerly Thomson-Reuters) Book Citation Index }\end{array}$ & 0.848 \\
\hline $\begin{array}{l}\text { Citations of books and book chapters in the Clarivate Analytics (for- } \\
\text { merly Thomson-Reuters) Book Citation Index }\end{array}$ & 0.940 \\
\hline average citations - books and book chapters & 0.765 \\
\hline standard deviation citations books and book chapters & 0.904 \\
\hline Sense Quality Indicator for multivariate analysis & 0.665 \\
\hline Harvard Library number of titles (books only) & 0.852 \\
\hline $\begin{array}{l}\text { Harvard HOLLIS ratio of books checked out per total holdings (books } \\
\text { only) }\end{array}$ & 0.839 \\
\hline $\begin{array}{l}\text { average citations - books in the Clarivate Analytics (formerly Thom- } \\
\text { son-Reuters) book citation index }\end{array}$ & 0.856 \\
\hline
\end{tabular}




\begin{tabular}{|l|c|}
\hline & Variance explained \\
\hline Japanese NACSIS top library outreach (books only) & 0.843 \\
\hline Japanese NACSIS $200^{\text {th }}$ library outreach (books only) & 0.925 \\
\hline Swedish LIBRIS top library outreach & 0.707 \\
\hline Swedish LIBRIS 50 ${ }^{\text {th }}$ library outreach & 0.765 \\
\hline number of references about the company in books - Questia & 0.843 \\
\hline $\begin{array}{l}\text { number of references about the company in scholarly journals - } \\
\text { Questia }\end{array}$ & 0.938 \\
\hline number of references about the company in magazines - Questia & 0.946 \\
\hline number of references about the company in newspapers - Questia & 0.932 \\
\hline Items in ECLAS catalogue Brussels & 0.899 \\
\hline $\begin{array}{l}\text { Items in World Bank/IMF JOLIS library catalogue Washington } \\
\text { (books only) }\end{array}$ & 0.936 \\
\hline Items in the IndCat (India) Union catalog & 0.886 \\
\hline total number of recent titles & 0.968 \\
\hline Recent titles with more than 50 circulation & 0.978 \\
\hline Recent titles with more than 500 circulation & 0.727 \\
\hline$\%$ of titles with a circulation of more than 500 & 0.823 \\
\hline$\%$ of titles with a circulation between 50 and 500 & 0.914 \\
\hline$\%$ of titles with a circulation of less than 50 & 0.969 \\
\hline
\end{tabular}

Table 3

The multivariate promax factor model of publisher market power - cumulative percentage of total variance explained and Eigenvalues

\begin{tabular}{|l|c|c|c|}
\hline & Eigenvalues & $\begin{array}{c}\text { \% of variance } \\
\text { explained }\end{array}$ & $\begin{array}{c}\text { Cumulated } \\
\text { percentage of } \\
\text { variance explained }\end{array}$ \\
\hline overall global standing of the company & 10,156 & 33,855 & 33,855 \\
\hline company is a factor on the market & 3,471 & 11,569 & 45,424 \\
\hline $\begin{array}{l}\text { company impact on the global political } \\
\text { and economic debate }\end{array}$ & 3,012 & 10,041 & 55,465 \\
\hline successfully distributing best-sellers & 2,570 & 8,567 & 64,032 \\
\hline impact on the scholarly community & 2,193 & 7,309 & 71,341 \\
\hline $\begin{array}{l}\text { successfully distributing production to } \\
\text { more than 50 libraries }\end{array}$ & 1,689 & 5,628 & 76,970 \\
\hline output during the last 5 years & 1,587 & 5,291 & 82,261 \\
\hline outstanding academic quality & 1,105 & 3,684 & $\mathbf{8 5 , 9 4 5}$ \\
\hline
\end{tabular}


Table 4

Factor loadings

\begin{tabular}{|c|c|c|c|c|c|c|c|c|}
\hline & 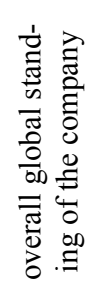 & 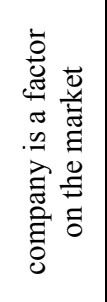 & 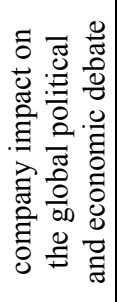 & 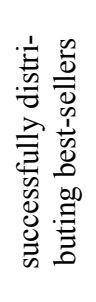 & 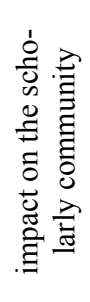 & 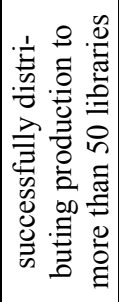 & 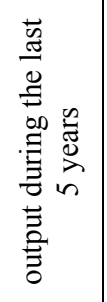 & 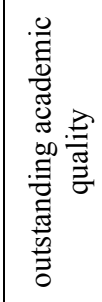 \\
\hline $\begin{array}{l}\text { Wikipedia monthly down- } \\
\text { loads, English, last year }\end{array}$ & 0.775 & 0.284 & 0.118 & 0.304 & 0.312 & 0.062 & -0.067 & 0.044 \\
\hline $\begin{array}{l}\text { OCLC WC number of books } \\
\text { published in the last } 5 \text { years }\end{array}$ & 0.514 & 0.974 & 0.262 & 0.274 & 0.067 & 0.233 & 0.017 & 0.049 \\
\hline $\begin{array}{l}\text { book (last } 5 \text { years) with the } \\
\text { highest global library circula- } \\
\text { tion rate }\end{array}$ & 0.509 & 0.124 & 0.010 & 0.808 & 0.084 & 0.297 & -0.034 & -0.008 \\
\hline $\begin{array}{l}\text { book (last } 5 \text { years) with the } \\
50^{\text {th }} \text { highest global library cir- } \\
\text { culation rate }\end{array}$ & 0.459 & 0.226 & 0.081 & 0.969 & 0.201 & 0.134 & -0.003 & 0.080 \\
\hline $\begin{array}{l}\text { continuity of performance - } \\
\text { top } 50 \text { books (last } 5 \text { years) }\end{array}$ & 0.352 & 0.243 & 0.287 & 0.863 & 0.223 & 0.115 & 0.072 & 0.136 \\
\hline $\begin{array}{l}\text { Quantity Indicator - number } \\
\text { of books and book chapters in } \\
\text { the Clarivate Analytics (for- } \\
\text { merly Thomson-Reuters) } \\
\text { Book Citation Index }\end{array}$ & 0.376 & 0.873 & 0.189 & 0.253 & 0.049 & 0.456 & 0.131 & 0.093 \\
\hline $\begin{array}{l}\text { Citations of books and book } \\
\text { chapters in the Clarivate Ana- } \\
\text { lytics (formerly Thomson- } \\
\text { Reuters) Book Cittation Index }\end{array}$ & 0.413 & 0.942 & 0.223 & 0.280 & 0.182 & 0.422 & 0.006 & 0.111 \\
\hline $\begin{array}{l}\text { average citations - books and } \\
\text { book chapters }\end{array}$ & 0.232 & 0.126 & 0.181 & 0.093 & 0.852 & 0.027 & -0.117 & 0.208 \\
\hline $\begin{array}{l}\text { standard deviation citations } \\
\text { books and book chapters }\end{array}$ & 0.458 & 0.214 & 0.502 & 0.353 & 0.845 & 0.221 & -0.074 & 0.235 \\
\hline $\begin{array}{l}\text { Sense Quality Indicator for } \\
\text { multivariate analysis }\end{array}$ & 0.705 & 0.120 & 0.066 & 0.504 & 0.082 & 0.370 & -0.077 & 0.038 \\
\hline $\begin{array}{l}\text { Harvard Library number of ti- } \\
\text { tles (books only) }\end{array}$ & 0.751 & 0.777 & 0.282 & 0.314 & 0.102 & 0.241 & -0.085 & 0.010 \\
\hline $\begin{array}{l}\text { Harvard HOLLIS ratio of } \\
\text { books checked out per total } \\
\text { holdings (books only) }\end{array}$ & 0.064 & -0.038 & -0.029 & 0.105 & 0.233 & 0.194 & -0.025 & 0.865 \\
\hline $\begin{array}{l}\text { average citations - books in } \\
\text { the Clarivate Analytics (for- } \\
\text { merly Thomson-Reuters) } \\
\text { book citation index }\end{array}$ & 0.398 & 0.130 & 0.230 & 0.265 & 0.910 & -0.003 & -0.115 & -0.043 \\
\hline $\begin{array}{l}\text { Japanese NACSIS top library } \\
\text { outreach (books only) }\end{array}$ & 0.816 & 0.334 & 0.271 & 0.494 & 0.445 & 0.181 & -0.119 & 0.400 \\
\hline $\begin{array}{l}\text { Japanese NACSIS } 200^{\text {th }} \text { lib- } \\
\text { rary outreach (books only) }\end{array}$ & 0.941 & 0.536 & 0.315 & 0.489 & 0.381 & 0.168 & -0.090 & 0.067 \\
\hline
\end{tabular}


Tausch • The Market Power of Global Scientific Publishing Companies

\begin{tabular}{|c|c|c|c|c|c|c|c|c|}
\hline & 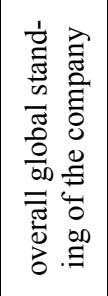 & 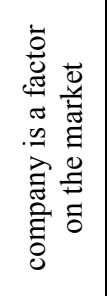 & 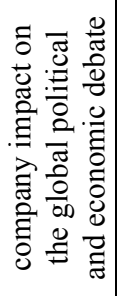 & 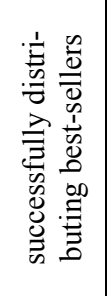 & 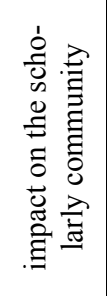 & 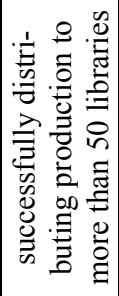 & 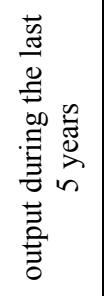 & 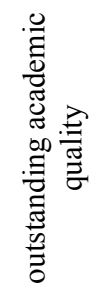 \\
\hline $\begin{array}{l}\text { Swedish LIBRIS top library } \\
\text { outreach }\end{array}$ & 0.809 & 0.390 & 0.333 & 0.509 & 0.239 & 0.122 & 0.021 & 0.179 \\
\hline $\begin{array}{l}\text { Swedish LIBRIS 50th library } \\
\text { outreach }\end{array}$ & 0.716 & 0.462 & 0.333 & 0.715 & 0.151 & 0.216 & 0.134 & -0.067 \\
\hline $\begin{array}{l}\text { number of references about } \\
\text { the company in books - } \\
\text { Questia }\end{array}$ & 0.886 & 0.196 & 0.302 & 0.426 & 0.284 & 0.192 & -0.034 & -0.035 \\
\hline $\begin{array}{l}\text { number of references about } \\
\text { the company in scholarly } \\
\text { journals - Questia }\end{array}$ & \begin{tabular}{|l|}
0.759 \\
\end{tabular} & 0.350 & 0.795 & 0.313 & 0.295 & 0.114 & 0.020 & .009 \\
\hline $\begin{array}{l}\text { number of references about } \\
\text { the company in magazines - } \\
\text { Questia }\end{array}$ & \begin{tabular}{|l|}
0.295 \\
\end{tabular} & 0.232 & 0.953 & 0.165 & 0.317 & -0.043 & 0.004 & 0.003 \\
\hline $\begin{array}{l}\text { number of references about } \\
\text { the company in newspapers - } \\
\text { Questia }\end{array}$ & 0.261 & 0.761 & 0.752 & 0.175 & 0.139 & 0.080 & 0.036 & 0.046 \\
\hline $\begin{array}{l}\text { Items in ECLAS catalogue } \\
\text { Brussels }\end{array}$ & \begin{tabular}{|l|}
0.298 \\
\end{tabular} & 0.937 & 0.208 & 0.175 & 0.080 & 0.214 & -0.080 & 0.045 \\
\hline $\begin{array}{l}\text { Items in World Bank/IMF } \\
\text { JOLIS library catalogue } \\
\text { Washington (books only) }\end{array}$ & 0.270 & 0.207 & 0.948 & 0.100 & 0.306 & 0.052 & 0.015 & 0.009 \\
\hline $\begin{array}{l}\text { Items in the IndCat (India) } \\
\text { Union catalog }\end{array}$ & 0.855 & 0.556 & 0.379 & 0.204 & 0.257 & -0.011 & -0.008 & 0.001 \\
\hline total number of recent titles & -0.073 & -0.008 & 0.034 & 0.014 & -0.137 & -0.077 & 0.982 & -0.093 \\
\hline $\begin{array}{l}\text { Recent titles with more than } \\
50 \text { circulation }\end{array}$ & -0.036 & 0.031 & 0.056 & 0.042 & -0.109 & 0.025 & 0.986 & -0.074 \\
\hline $\begin{array}{l}\text { Recent titles with more than } \\
500 \text { circulation }\end{array}$ & 0.078 & 0.046 & 0.643 & 0.059 & -0.141 & 0.233 & 0.219 & 0.484 \\
\hline $\begin{array}{l}\% \text { of titles with a circulation } \\
\text { of more than } 500\end{array}$ & 0.154 & 0.206 & 0.185 & 0.106 & -0.153 & 0.571 & -0.281 & 0.778 \\
\hline $\begin{array}{l}\% \text { of titles with a circulation } \\
\text { between } 50 \text { and } 500\end{array}$ & 0.165 & 0.338 & 0.032 & 0.170 & 0.057 & 0.932 & 0.013 & 0.221 \\
\hline $\begin{array}{l}\% \text { of titles with a circulation } \\
\text { of less than } 50\end{array}$ & -0.188 & -0.350 & -0.088 & -0.177 & 0.003 & -0.965 & 0.082 & -0.442 \\
\hline
\end{tabular}


Table 5

Correlations between the factors of publisher market power

\begin{tabular}{|c|c|c|c|c|c|c|c|c|}
\hline Component & 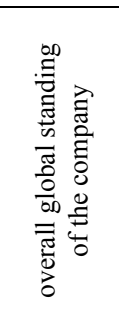 & 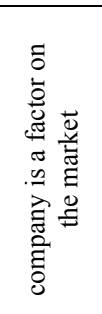 & 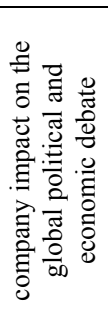 & 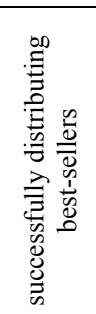 & 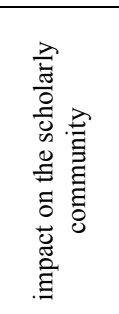 & 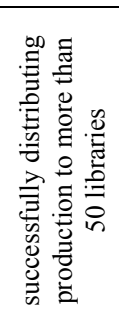 & 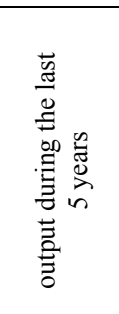 & 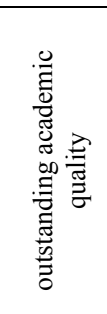 \\
\hline $\begin{array}{l}\text { overall global } \\
\text { standing of the } \\
\text { company }\end{array}$ & 1.000 & 0.417 & 0.319 & 0.493 & 0.304 & 0.196 & -0.055 & 0.064 \\
\hline $\begin{array}{l}\text { company is a } \\
\text { factor on the } \\
\text { market }\end{array}$ & 0.417 & 1.000 & 0.295 & 0.223 & 0.109 & 0.251 & 0.004 & 0.061 \\
\hline $\begin{array}{l}\text { company impact } \\
\text { on the global po- } \\
\text { litical and eco- } \\
\text { nomic debate }\end{array}$ & 0.319 & 0.295 & 1.000 & 0.160 & 0.209 & 0.056 & 0.063 & 0.128 \\
\hline $\begin{array}{l}\text { successfully dis- } \\
\text { tributing best- } \\
\text { sellers }\end{array}$ & 0.493 & 0.223 & 0.160 & 1.000 & 0.194 & 0.229 & 0.036 & 0.075 \\
\hline $\begin{array}{l}\text { impact on the } \\
\text { scholarly com- } \\
\text { munity }\end{array}$ & 0.304 & 0.109 & 0.209 & 0.194 & 1.000 & -0.046 & -0.105 & 0.043 \\
\hline $\begin{array}{l}\text { successfully dis- } \\
\text { tributing produc- } \\
\text { tion to more than } \\
50 \text { libraries }\end{array}$ & 0.196 & 0.251 & 0.056 & 0.229 & -0.046 & 1.000 & -0.043 & 0.328 \\
\hline $\begin{array}{l}\text { output during the } \\
\text { last } 5 \text { years }\end{array}$ & -0.055 & 0.004 & 0.063 & 0.036 & -0.105 & -0.043 & 1.000 & -0.088 \\
\hline $\begin{array}{l}\text { outstanding } \\
\text { academic quality }\end{array}$ & 0.064 & 0.061 & 0.128 & 0.075 & 0.043 & 0.328 & -0.088 & 1.000 \\
\hline
\end{tabular}

Table 6 now lists the final outcome of our study. It is based on the factor analytical results described above. According to our results, any scholar or journal, publishing with Oxford University Press, Springer, Cambridge University Press, Routledge, World Bank, Princeton University Press, Elsevier, CRC Press, University of Chicago Press, and University of California Press is on the 'safe side', and these companies belong to the global top 20 per cent of the book publishing industry. 
Table 6

The final classification of global publishers' market power according to our promax factor analytical model (factors weighted according to their Eigenvalues)

\begin{tabular}{|c|c|c|c|}
\hline & $\begin{array}{l}\text { Overall Quality } \\
\text { Indicator }\end{array}$ & Rank & $\begin{array}{c}\text { percentile } \\
\text { performance }\end{array}$ \\
\hline Oxford University Press & 45,538 & 1 & 1,961 \\
\hline Springer & 43,102 & 2 & 3,922 \\
\hline Cambridge University Press & 38,126 & 3 & 5,882 \\
\hline Routledge & 33,592 & 4 & 7,843 \\
\hline World Bank & 24,110 & 5 & 9,804 \\
\hline Princeton University Press & 23,341 & 6 & 11,765 \\
\hline Elsevier & 20,351 & 7 & 13,725 \\
\hline CRC Press & 14,633 & 8 & 15,686 \\
\hline University of Chicago Press & 14,564 & 9 & 17,647 \\
\hline University of California Press & 10,678 & 10 & 19,608 \\
\hline Palgrave Macmillan & 10,546 & 11 & 21,569 \\
\hline MIT Press & 10,527 & 12 & 23,529 \\
\hline Yale University Press & 9,289 & 13 & 25,490 \\
\hline University of North Carolina Press & 5,686 & 14 & 27,451 \\
\hline De Gruyter & 5,571 & 15 & 29,412 \\
\hline Wiley-Blackwell & 4,036 & 16 & 31,373 \\
\hline Kluwer Academic Publishers & 2,081 & 17 & 33,333 \\
\hline University of Pennsylvania Press & 1,751 & 18 & 35,294 \\
\hline Johns Hopkins University Press & 1,416 & 19 & 37,255 \\
\hline Brill & 1,396 & 20 & 39,216 \\
\hline Nova Science Publishers & 0,958 & 21 & 41,176 \\
\hline University of Illinois Press & $-0,753$ & 22 & 43,137 \\
\hline Duke University Press & $-1,034$ & 23 & 45,098 \\
\hline University of Washington Press & $-2,144$ & 24 & 47,059 \\
\hline Edward Elgar & $-5,559$ & 25 & 49,020 \\
\hline Rodopi & $-5,772$ & 26 & 50,980 \\
\hline Edinburgh University Press & $-6,666$ & 27 & 52,941 \\
\hline Island Press & $-7,005$ & 28 & 54,902 \\
\hline World Scientific and Engineering & $-7,197$ & 29 & 56,863 \\
\hline IEEE & $-7,492$ & 30 & 58,824 \\
\hline John Benjamins & $-7,562$ & 31 & 60,784 \\
\hline CABI & $-7,806$ & 32 & 62,745 \\
\hline University of New Mexico Press & $-8,674$ & 33 & 64,706 \\
\hline Ios Press & $-8,882$ & 34 & 66,667 \\
\hline Karger & $-9,509$ & 35 & 68,627 \\
\hline L'Harmattan & $-11,850$ & 36 & 70,588 \\
\hline Earthscan Publications Ltd. & $-12,054$ & 37 & 72,549 \\
\hline Catena Verlag & $-12,446$ & 38 & 74,510 \\
\hline Transaction Publishing & $-12,674$ & 39 & 76,471 \\
\hline Channel View Publications & $-12,776$ & 40 & 78,431 \\
\hline (UCB) University of British Columbia Press & $-12,866$ & 41 & 80,392 \\
\hline
\end{tabular}




\begin{tabular}{|l|c|c|c|}
\hline & $\begin{array}{c}\text { Overall Quality } \\
\text { Indicator }\end{array}$ & Rank & $\begin{array}{c}\text { percentile } \\
\text { performance }\end{array}$ \\
\hline Wilfrid Laurier University Press & $-13,277$ & 42 & 82,353 \\
\hline ASM Press & $-13,632$ & 43 & 84,314 \\
\hline IWA Publishing & $-13,722$ & 44 & 86,275 \\
\hline Woodhead Publishing & $-14,552$ & 45 & 88,235 \\
\hline Equinox & $-14,931$ & 46 & 90,196 \\
\hline Wageningen & $-14,961$ & 47 & 92,157 \\
\hline Resources for the Future & $-16,757$ & 48 & 94,118 \\
\hline Ateneo de Manila University & $-17,857$ & 49 & 96,078 \\
\hline Nottingham University Press & $-20,384$ & 50 & 98,039 \\
\hline WIT Press & $-20,495$ & 51 & 100,000 \\
\hline
\end{tabular}

\section{Conclusions}

This article evaluated tendencies and trends of the global academic publishing industry, vital for any reasonable long-term publication strategy planning in research. Such analyses are made possible today by the OCLC Worldcat. This combined global library catalogue (union catalogue) OCLC was founded in America in 1967 and today integrates library collections ranging from northern Norway to Chile, and from California to Europe and Africa on to the Asia Pacific Region, including an ever-growing number of libraries in the BRIICS countries. Comparisons based on the wealth of these data can even be accessed via the freely available versions of the OCLC 'Worldcat', such as 'OCLC Classify' or the New Zealand Library Portal 'TE PUNA' ('TE PUNA on World Cat'), or by the full subscription-based 'OCLC First Search' version of the OCLC Worldcat.

Based on OCLC Worldcat data, recent contributions in the expanding discipline of scientometry and bibliometrics have started to study the global presence of publications in global libraries, which are the main buyers of our academic publications in the world today. Such methods are absolutely necessary to design successful academic strategies to distribute effectively scientific knowledge in the age of globalization around the globe.

We can estimate from the OCLC data that of the more than 300 million books held in global libraries, more than 120 million books were published in English, 43 million in German, and around 31 million in French. Especially German as a scientific language is on the retreat over the last decades. Of the 20.8 million books published in the last five years, 45 per cent were published in English, and in the field of political science, for example, this share was even 55 per cent. The concentration of the publication process on a global scale is enormous. In the field of political science alone, 13 leading publishers with an output of more than 400 political science books during the last five years published none the less than 38 per cent of the 1.7 million English language political science titles during the last five years.

Our basic idea was simple, not to say downright vulgar. Is a book or a book series or a scientific journal important, it must be surely not only cited internationally, but it must also be physically or electronically present in as many global libraries as possible, because after all: what counts, is global and geographically diverse readership.

Even high-quality English language books might find it sometimes hard to find an appropriate library outreach of more than 50 global libraries, especially if the price of a book is high or if your publisher's marketing facilities are not so well developed. A flagship Russian language publication like 'Mirovaia ekonomika i mezhdunarodnye otnosheniia', which was studied in the days of the Cold War by hundreds of Western security and defense experts to 
find clues as to what 'the Soviet Enemy' is planning next, only makes it to 125 global libraries. As we show in our article, there are severe international market constraints even for English language academic publications, printed at any of the University Presses of the world today: only 1.93 per cent of the global University Press output of the last five years reached more than 500 global libraries.

In our essay, we compare book company global impact figures with results from an earlier bibliometric study, which already used library presence results from union catalogues with counting procedures, such as in India, Japan, and Sweden (Tausch 2017). In our essay, we combined the available OCLC Worldcat data with results of the Tausch (2017) study, which also used existing rankings of global academic publishing companies published in the literature, and data from the newly created Clarivate Analytics (formerly Thomson-Reuters) 'Book Citation Index'. Our new multivariate attempt, combining all these data, is based on factor analysis of 32 variables, and our promax factor analytical model established that there are eight factors of global publisher impact, explaining almost 86 per cent of total variance:

1. overall global standing of the company;

2. company as a factor on the market;

3. company impact on the global political and economic debate;

4. successfully distributing best-sellers;

5. impact on the scholarly community;

6. successfully distributing production to more than 50 global Worldcat libraries;

7. output during the last 5 years;

8 . outstanding academic quality.

Of the 51 companies with complete data under investigation here, the following companies were classified in the upper half: Oxford University Press; Springer; Cambridge University Press; Routledge; World Bank; Princeton University Press; Elsevier; CRC Press; University of Chicago Press; University of California Press; Palgrave Macmillan; MIT Press; Yale University Press; University of North Carolina Press; De Gruyter; WileyBlackwell; Kluwer Academic Publishers; University of Pennsylvania Press; Johns Hopkins University Press; Brill; Nova Science Publishers; University of Illinois Press; Duke University Press; University of Washington Press; and Edward Elgar. Scientists, wanting to get global audiences, are well advised to publish with those companies; and journal editors, wanting to get a global distribution for their journals, are equally well advised to cooperate with them.

\section{NOTES}

${ }^{1}$ http://www.shanghairanking.com/ARWU2017.html.

${ }^{2} \mathrm{http}: / /$ www.scimagoir.com/.

${ }^{3} \mathrm{https}: / /$ www.elsevier.com/solutions/scopus.

${ }^{4}$ The journal is indexed in SCOPUS, see:

https://www.scimagojr.com/journalsearch.php?q=19900191475\&tip=sid\&clean=0.

${ }^{5} \mathrm{http}: / /$ www.sense.nl/organisation/documentation.

${ }^{6}$ Torres-Salinas et al. (2013); see also https://www.researchgate.net/publication/267869924_Bib liometric_Indicators_for_Publishers_Data_processing_indicators_and_interpretation. See also http:// wokinfo.com/products_tools/multidisciplinary/bookcitationindex/.

${ }^{7} \mathrm{http}: / /$ wokinfo.com/mbl/publishers/.

${ }^{8} \mathrm{https}: / /$ www.rug.nl/research/portal/publications/search.html.

${ }^{9}$ OCLC First Search, by courtesy of OCLC Company.

${ }^{10}$ OCLC First Search, by courtesy of OCLC Company. 
${ }^{11}$ OCLC First Search, by courtesy of OCLC Company.

${ }^{12}$ TE PUNA on Worldcat, https://tepuna.on.worldcat.org/advancedsearch?databaseList=.

${ }^{13}$ TE PUNA on Worldcat, https://tepuna.on.worldcat.org/advancedsearch?databaseList=. baseList $=$.

${ }^{14}$ Calculated from TE PUNA on Worldcat, https://tepuna.on.worldcat.org/advancedsearch?data

${ }^{15}$ Calculated from TE PUNA on Worldcat, available at: https://tepuna.on.worldcat.org/advan cedsearch?databaseList $=$.

${ }^{16}$ OCLC First Search, by courtesy of OCLC Company.

${ }^{17}$ OCLC First Search, by courtesy of OCLC Company.

${ }^{18}$ OCLC First Search, by courtesy of OCLC Company.

${ }^{19} \mathrm{http} / / /$ tools.wmflabs.org/pageviews/?project=en.wikipedia.org\&platform=all-access\&agent $=$ user \&range $=$ latest $-20 \&$ pages $=$ Cat $\mid$ Dog .

${ }^{20}$ Torres-Salinas et al. (2013); https://www.researchgate.net/publication/267869924_Bibliomet ric_Indicators_for_Publishers_Data_processing_indicators_and_interpretation.

${ }^{21}$ Torres-Salinas et al. (2013);

net/publication/267869924_Bibliometric_Indicators_for_Publishers_Data_processing_indicators_and_ interpretation.

$22 \mathrm{http} / /$ hollis.harvard.edu/primo_library/libweb/action/search.do?mode=Advanced\&ct=Advanced Search\&dscnt $=0 \&$ dstmp $=1444746207332 \&$ vid $=$ HVD.

${ }^{23} \mathrm{https} / / /$ www.Questia.com/.

${ }^{24}$ Torres-Salinas et al. (2013); https://www.researchgate.net/publication/267869924_Bibliomet ric_Indicators_for_Publishers_Data_processing_indicators_and_interpretation.

${ }^{25}$ Torres-Salinas et al. (2013); https://www.researchgate.net/publication/267869924_Bibliomet ric_Indicators_for_Publishers_Data_processing_indicators_and_interpretation.

${ }^{26} \mathrm{http}: / / \mathrm{www} . \mathrm{sense} . \mathrm{nl} /$ organisation/documentation.

$27 \mathrm{http}: / /$ hollis.harvard.edu/primo_library/libweb/action/search.do?mode=Advanced\&ct=Advanced Search\&dscnt $=0 \&$ dstmp $=1444746207332 \&$ vid $=$ HVD.

${ }^{28}$ Torres-Salinas et al. (2013); https://www.researchgate.net/publication/267869924_Bibliomet ric_Indicators_for_Publishers_Data_processing_indicators_and_interpretation.

${ }^{29} \mathrm{https}: / / \mathrm{www}$. Questia.com/.

${ }^{30} \mathrm{http} / / /$ ci.nii.ac.jp/books/.

${ }^{31} \mathrm{http} / / /$ ci.nii.ac.jp/books/.

${ }^{32} \mathrm{http} / / /$ libris.kb.se/form_extended.jsp?f=ext.

${ }^{33} \mathrm{http} / / /$ libris.kb.se/form_extended.jsp?f=ext.

${ }^{34} \mathrm{http}: / /$ ec.europa.eu/eclas/F.

${ }^{35} \mathrm{http}$ //external.worldbankimflib.org/uhtbin/webcat/.

${ }^{36} \mathrm{http}: / /$ indcat.inflibnet.ac.in/.

${ }^{37} \mathrm{https}: / /$ www.Questia.com/.

${ }^{38} \mathrm{https} / / /$ www.Questia.com/.

\section{REFERENCES}

Abramson, P. R., and Inglehart, R. F. 2009. Value Change in Global Perspective. Ann Arbor, MI: University of Michigan Press.

Inglehart, R. 2002. Islam, Gender, Culture, and Democracy. Willowdale, ON, Canada: de Sitter.

Piketty, T. 2014. Capital in the $21^{\text {st }}$ Century. Transl. by A. Goldhammer. Cambridge, MA: Belknap Press, An Imprint of Harvard University Press. 
Sahel, J. A. 2011. Quality versus Quantity: Assessing Individual Research Performance. Science translational medicine 3(84): 84cm13-84cm13. URL: https://www.ncbi. nlm.nih.gov/pmc/articles/PMC3338409/.

Tausch, A. 2015a. Die Buchpublikationen der Nobelpreis-Ökonomen und die führenden Buchverlage der Disziplin. Eine bibliometrische Analyse. Bibliotheksdienst 51 (3-4): 339-373.

Tausch, A. 2015b. The Political Algebra of Global Value Change. General Models and Implications for the Muslim World. With Almas Heshmati and Hichem Karoui. New York: Nova Science Publishers.

Torres-Salinas, D., Robinson-García, N., and López-Cózar, E. D. 2012. Towards a Book Publishers Citation Reports. First Approach Using the Book Citation Index. arXiv preprint arXiv: 1207.7067.

Torres-Salinas, D., Robinson-García, N., Cabezas-Clavijo, Á., and Jiménez-Contreras, E. 2014. Analyzing the Citation Characteristics of Books: Edited Books, Book Series and Publisher Types in the Book Citation Index. Scientometrics 98 (3): 2113-2127.

Torres-Salinas, D., Robinson-Garcia, N., Miguel Campanario, J., and Delgado López-Cózar, E. 2014. Coverage, Field Specialization and the Impact of Scientific Publishers Indexed in the Book Citation Index. Online Information Review 38 (1): 24-42.

Torres-Salinas, D., Rodríguez-Sánchez, R., Robinson-García, N., Fdez-Valdivia, J., and García, J. A. 2013. Mapping Citation Patterns of Book Chapters in the Book Citation Index. Journal of Infometrics 7 (2): 412-424.

van der Vliet, E. C. L. 2008. The Early State, the Polis and State Formation in Early Greece. Social Evolution \& History 7 (2): 197-221.

White, H. D., Boell, S. K., Davis, M. Yu. H., Wilson, C. S., Cole, Fletcher T. H. J. 2009. Libcitations: A Measure for Comparative Assessment of Book Publications in the Humanities and Social Sciences. Journal of the American Society for Information Science \& Technology 60 (6): 1083-1096.

Zuccala, A., Guns, R., Cornacchia, R., and Bod, R. 2015. Can we Rank Scholarly Book Publishers? A Bibliometric Experiment with the Field of History. Journal of the Association for Information Science and Technology 66 (7): 1333-1347. 


\section{Appendix}

\section{Original data used in the multivariate model}

Table 1

\begin{tabular}{|c|c|c|c|c|c|c|c|c|c|c|c|c|}
\hline Publisher & 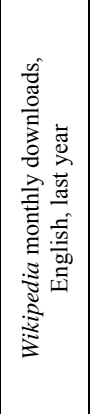 & 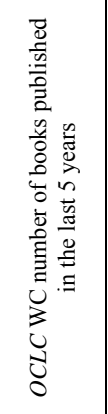 & 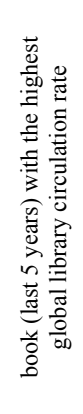 & 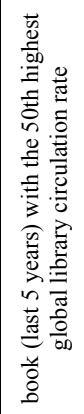 & 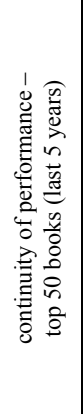 & 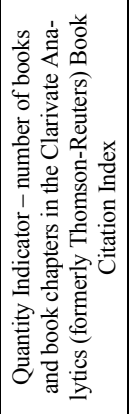 & 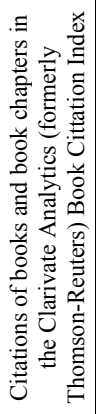 & 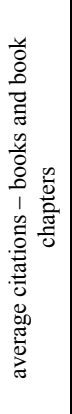 & 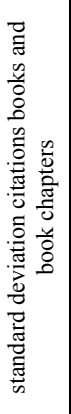 & 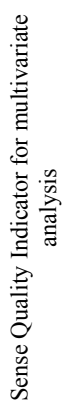 & 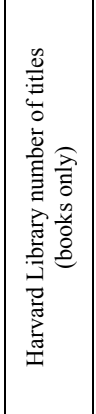 & 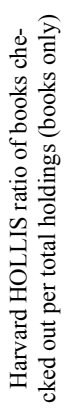 \\
\hline \begin{tabular}{|l|} 
(UCB) Univer- \\
sity of British \\
Columbia Press \\
\end{tabular} & 333 & 127 & 458 & 2 & 0.4 & 981 & 475 & 0.5 & 1.9 & 2 & 844 & 4.4 \\
\hline Anthem Press & & 1,969 & 1,329 & 690 & 51.9 & 183 & 16 & 0.1 & 0.4 & 1 & 300 & 12.0 \\
\hline ASM Press & 42 & 801 & 948 & 291 & 30.7 & 20 & 2 & 0.1 & 0.5 & 2 & 222 & 5.9 \\
\hline $\begin{array}{l}\text { Ateneo de Ma- } \\
\text { nila University }\end{array}$ & 83 & 251 & 56 & 14 & 25.0 & 201 & 23 & 0.1 & 0.7 & 2 & 304 & 10.9 \\
\hline Brill & 576 & 44,343 & 917 & 847 & 92.4 & 2,503 & 352 & 0.1 & 0.9 & 3 & 12,598 & 5.7 \\
\hline CABI & 449 & 2,693 & 304 & 69 & 22.7 & 2,235 & 1,148 & 0.5 & 2 & 3 & 204 & 2.9 \\
\hline \begin{tabular}{|l|} 
Cambridge \\
University Press \\
\end{tabular} & 13,393 & 100,622 & 1,086 & 448 & 41.3 & 17,743 & 13,597 & 0.8 & 7 & 4 & 31,265 & 8.3 \\
\hline Catena Verlag & 569 & 149 & 28 & 2 & 7.1 & 2 & 5 & 2.5 & 3.5 & 2 & 27 & 14.8 \\
\hline \begin{tabular}{|l|} 
Channel View \\
Publications
\end{tabular} & 124 & 862 & 652 & 124 & 19.0 & 14 & 3 & 0.2 & 0.8 & 2 & 52 & 9.6 \\
\hline CRC Press & 4,312 & 8,523 & 931 & 922 & 99.0 & 3,661 & 4.621 & 1.3 & 9.6 & 3 & 3,669 & 71.0 \\
\hline De Gruyter & 541 & 7,5258 & 1,453 & 1,310 & 90.2 & 3,909 & 1,931 & 0.5 & 3.5 & 2 & 12,928 & 4.5 \\
\hline $\begin{array}{l}\text { Duke University } \\
\text { Press }\end{array}$ & 1,769 & 5,293 & 609 & 306 & 50.2 & 23 & 4 & 0.2 & 0.7 & 3 & 3,522 & 10.7 \\
\hline \begin{tabular}{|l} 
Earthscan \\
Publications \\
Ltd. \\
\end{tabular} & 580 & 1,109 & 492 & 80 & 16.3 & 41 & 6 & 0.2 & 0.7 & 3 & 1,005 & 5.4 \\
\hline \begin{tabular}{|l|} 
Edinburgh \\
University Press \\
\end{tabular} & 957 & 9 & 7 & 0 & 0.0 & 2,332 & 373 & 0.2 & 1.1 & 2 & 2,120 & 11.4 \\
\hline Edward Elgar & 1,731 & 19,257 & 505 & 125 & 24.8 & 13,298 & 4,019 & 0.3 & 1.6 & 3 & 3,412 & 5.5 \\
\hline Elsevier & 23,156 & 89,020 & 1,098 & 887 & 80.8 & 16,622 & 10,071 & 0.6 & 7.8 & 3 & 11,750 & 2.8 \\
\hline Equinox & 66 & 1,166 & 385 & 82 & 21.3 & 48 & 26 & 0.5 & 2 & 1 & 408 & 9.6 \\
\hline IEEE & 695 & 41,857 & 632 & 288 & 45.6 & 41 & 3 & 0.1 & 0.3 & 3 & 281 & 2.8 \\
\hline Ios Press & 363 & 2,478 & 1,436 & 902 & 62.8 & 155 & 36 & 0.2 & 1 & 2 & 350 & 2.6 \\
\hline Island Press & 385 & 2,177 & 1,439 & 802 & 55.7 & 16 & 5 & 0.3 & 0.6 & 3 & 1,050 & 2.8 \\
\hline IWA Publishing & 18 & 1,552 & 1,004 & 340 & 33.9 & 602 & 240 & 0.4 & 1.7 & 2 & 50 & 6.0 \\
\hline John Benjamins & 804 & 6,963 & 1,307 & 856 & 65.5 & 86 & 42 & 0.5 & 1.5 & 2 & 1,623 & 6.4 \\
\hline \begin{tabular}{|l|} 
Johns Hopkins \\
University Press
\end{tabular} & 2,361 & 4,752 & 1,415 & 1,153 & 81.5 & 399 & 155 & 0.4 & 1.3 & 4 & 5,191 & 4.1 \\
\hline
\end{tabular}


Tausch • The Market Power of Global Scientific Publishing Companies

\begin{tabular}{|c|c|c|c|c|c|c|c|c|c|c|c|c|}
\hline Publisher & 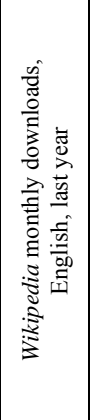 & 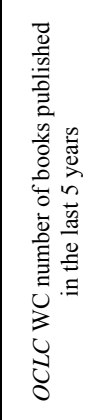 & 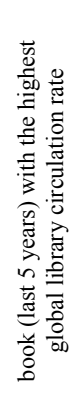 & 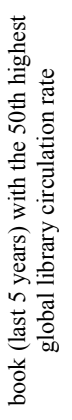 & 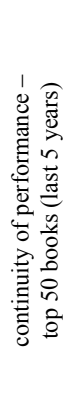 & 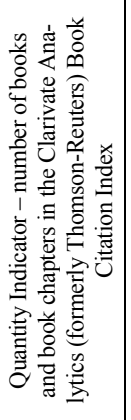 & 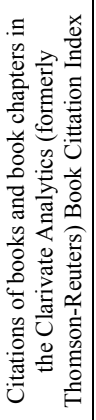 & 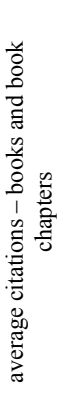 & 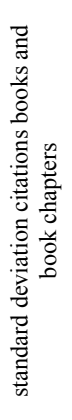 & 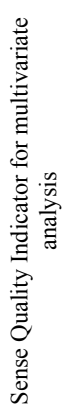 & 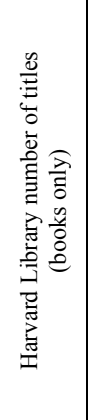 & 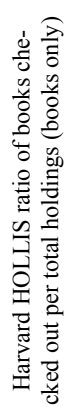 \\
\hline Karger & 404 & 2,437 & 118 & 62 & 52.5 & 460 & 183 & 0.4 & 1.4 & 3 & 3,006 & 1.0 \\
\hline $\begin{array}{l}\text { Kluwer Acade- } \\
\text { mic Publishers }\end{array}$ & 67 & 32,501 & 753 & 541 & 71.8 & 48 & 107 & 2.2 & 6.6 & 1 & 6,276 & 3.7 \\
\hline L'Harmattan & 355 & 49,148 & 94 & 53 & 56.4 & 13 & 0 & 0.0 & 0 & 2 & 31,685 & 0.4 \\
\hline MIT Press & 3,671 & 12,436 & 1,152 & 949 & 82.4 & 4,629 & 3,825 & 0.8 & 6.3 & 4 & 6,417 & 7.3 \\
\hline \begin{tabular}{|l|} 
Nottingham \\
University Press
\end{tabular} & 82 & 4 & 44 & 0 & 0.0 & 240 & 32 & 0.1 & 0.5 & 2 & 30 & 3.3 \\
\hline $\begin{array}{l}\text { Nova Science } \\
\text { Publishers }\end{array}$ & 1,794 & 16,574 & 1,075 & 702 & 65.3 & 15,727 & 3,953 & 0.3 & 1.1 & 2 & 1,087 & 4.0 \\
\hline $\begin{array}{l}\text { Oxford } \\
\text { University } \\
\text { Press }\end{array}$ & 20,425 & 130,981 & 1,480 & 853 & 57.6 & 34 & 33 & 1.0 & 4.8 & 4 & 55,790 & 5.9 \\
\hline $\begin{array}{l}\text { Palgrave } \\
\text { Macmillan }\end{array}$ & 4,708 & 120,585 & 1,310 & 646 & 49.3 & 45,306 & 13,352 & 0.3 & 1.6 & 3 & 14,615 & 10.9 \\
\hline $\begin{array}{l}\text { Praxis Publi- } \\
\text { shing Ltd. }\end{array}$ & & 911 & 428 & 37 & 8.6 & 43 & 5 & 0.1 & 0.6 & 1 & 577 & 1.0 \\
\hline $\begin{array}{l}\text { Princeton Uni- } \\
\text { versity Press }\end{array}$ & 4,255 & 22,344 & 1,589 & 968 & 60.9 & 6,207 & 11,254 & 1.8 & 16.8 & 4 & 9,982 & 6.3 \\
\hline $\begin{array}{l}\text { Resources for } \\
\text { the Future }\end{array}$ & 720 & 39 & 67 & 0 & 0.0 & 36 & 33 & 0.9 & 1.9 & 2 & 478 & 0.6 \\
\hline Rodopi & 721 & 4,042 & 874 & 801 & 91.6 & 55 & 11 & 0.2 & 0.9 & 2 & \begin{tabular}{|l|}
3,689 \\
\end{tabular} & 3.8 \\
\hline Routledge & 1,017 & 27,7276 & 726 & 667 & 91.9 & 27,511 & 11,585 & 0.4 & 3.7 & 3 & 35,594 & 8.3 \\
\hline $\begin{array}{l}\text { Royal Society of } \\
\text { Chemistry }\end{array}$ & & 3,761 & 1,271 & 711 & 55.9 & 826 & 1,311 & 1.6 & 13.1 & 3 & 267 & 4.1 \\
\hline Springer & 5,058 & 512,404 & 1,409 & 997 & 70.8 & 59,992 & 49,411 & 0.8 & 4.7 & 3 & 66,365 & 1.5 \\
\hline Studium Press & & 80 & 8 & 1 & 12.5 & 677 & 119 & 0.2 & 0.6 & 1 & 1,697 & 1.8 \\
\hline $\begin{array}{l}\text { Trans Tech } \\
\text { Publications }\end{array}$ & & 8,240 & 1,294 & 878 & 67.9 & 22 & 5 & 0.2 & 0.7 & 2 & 22 & 9.1 \\
\hline $\begin{array}{l}\text { Transaction } \\
\text { Publishing }\end{array}$ & 1,221 & 1,823 & 368 & 122 & 33.2 & 714 & 124 & 0.2 & 0.7 & 2 & 3,505 & 6.1 \\
\hline $\begin{array}{l}\text { Universidad } \\
\text { Nacional } \\
\text { Autonoma de } \\
\text { Mexico }\end{array}$ & & 4,647 & 163 & 41 & 25.2 & 88 & 3 & 0.0 & 0.3 & 1 & 5,945 & 3.5 \\
\hline \begin{tabular}{|l|} 
University of \\
California Press
\end{tabular} & 3,642 & 8,523 & 1,392 & 922 & 66.2 & 6,153 & 4,089 & 0.7 & 4.6 & 4 & 11,693 & 3.7 \\
\hline $\begin{array}{l}\text { University of } \\
\text { Chicago Press }\end{array}$ & 3,752 & 12,261 & 2,362 & 592 & 25.1 & 184 & 44 & 0.2 & 0.9 & 4 & 12,827 & 5.6 \\
\hline
\end{tabular}




\begin{tabular}{|c|c|c|c|c|c|c|c|c|c|c|c|c|}
\hline Publisher & 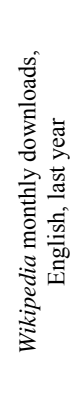 & 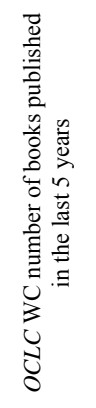 & 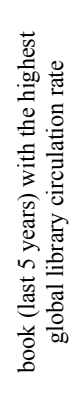 & 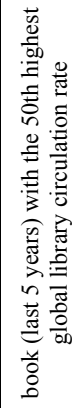 & 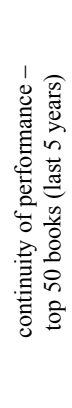 & 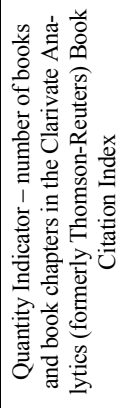 & 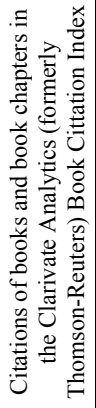 & 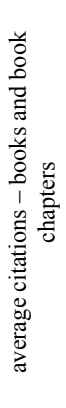 & 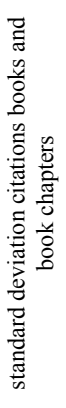 & 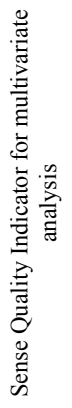 & 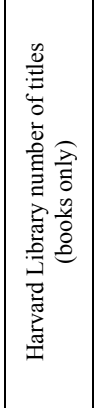 & 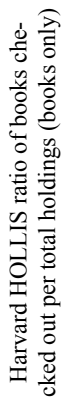 \\
\hline $\begin{array}{l}\text { University of Il- } \\
\text { linois Press }\end{array}$ & 1,789 & 3,769 & 1,451 & 979 & 67.5 & 2,480 & 794 & 0.3 & 1.7 & 2 & 6,414 & 3.6 \\
\hline $\begin{array}{l}\text { University of } \\
\text { New Mexico } \\
\text { Press }\end{array}$ & 306 & 1,718 & 927 & 566 & 61.1 & 12 & 0 & 0.0 & 0 & 2 & 2,311 & 2.6 \\
\hline $\begin{array}{l}\text { University of } \\
\text { North Carolina } \\
\text { Press }\end{array}$ & 1,310 & 4,024 & 1,354 & 840 & 62.0 & 2,646 & 1,981 & 0.8 & 3.1 & 3 & 4,069 & 4.8 \\
\hline $\begin{array}{l}\text { University of } \\
\text { Pennsylvania } \\
\text { Press }\end{array}$ & 1,019 & 7,690 & 1,299 & 496 & 38.2 & 3,697 & 2,755 & 0.8 & 3 & 3 & 5,118 & 4.8 \\
\hline $\begin{array}{l}\text { University of } \\
\text { Washington } \\
\text { Press }\end{array}$ & 587 & 2,493 & 963 & 808 & 83.9 & 661 & 188 & 0.3 & 1.9 & 2 & 3,342 & 3.5 \\
\hline Wageningen & 81 & 9,915 & 328 & 37 & 11.3 & 389 & 139 & 0.4 & 1 & 1 & 437 & 1.1 \\
\hline \begin{tabular}{|l|} 
Wiley- \\
Blackwell
\end{tabular} & 5,872 & 24,614 & 599 & 517 & 86.3 & 3,407 & 849 & 0.3 & 2.4 & 4 & 30,925 & 3.4 \\
\hline \begin{tabular}{|l|} 
Wilfrid Laurier \\
University Press
\end{tabular} & 255 & 15 & 6 & 0 & 0.0 & 496 & 142 & 0.3 & 1.2 & 2 & 676 & 1.3 \\
\hline WIT Press & 13 & 2,499 & 720 & 88 & 12.2 & 335 & 117 & 0.4 & 2.1 & 2 & 81 & 0.0 \\
\hline $\begin{array}{l}\text { Woodhead Pub- } \\
\text { lishing }\end{array}$ & 665 & 5,736 & 892 & 334 & 37.4 & 2,998 & 1,018 & 0.3 & 2 & 2 & 294 & 1.7 \\
\hline World Bank & 66 & 9,299 & 447 & 418 & 93.5 & 2,338 & 2,399 & 1.0 & 12.7 & 2 & 4,368 & 2.9 \\
\hline $\begin{array}{l}\text { World Scientific } \\
\text { and Engineering }\end{array}$ & 1,726 & 20,405 & 1,447 & 1,397 & 96.5 & 34 & 12 & 0.4 & 0.8 & 3 & 2,690 & 6.0 \\
\hline $\begin{array}{l}\text { Yale University } \\
\text { Press }\end{array}$ & 3,565 & 13,184 & 2,157 & 807 & 37.4 & 15 & 11 & 0.7 & 2.8 & 4 & 11,119 & 5.3 \\
\hline $\begin{array}{l}\text { University of } \\
\text { Pennsylvania } \\
\text { Press }\end{array}$ & 1,019 & 7,690 & 1,299 & 496 & 38.2 & 3,697 & 2,755 & 0.8 & 3 & 3 & 5,118 & 4.8 \\
\hline $\begin{array}{l}\text { University of } \\
\text { Washington } \\
\text { Press }\end{array}$ & 587 & 2,493 & 963 & 808 & 83.9 & 661 & 188 & 0.3 & 1.9 & 2 & 3,342 & 3.5 \\
\hline
\end{tabular}


Table 2

\begin{tabular}{|c|c|c|c|c|c|c|c|c|c|c|c|c|}
\hline Publisher & 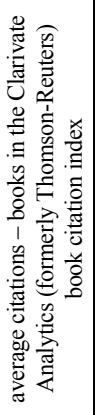 & 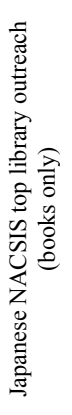 & 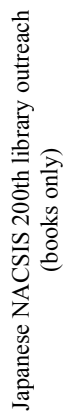 & 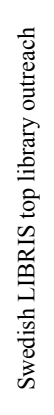 & 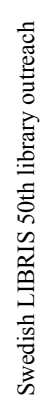 & 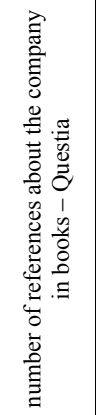 & 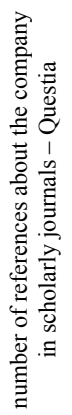 & 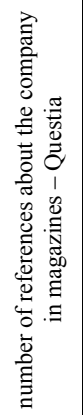 & 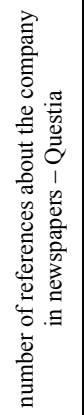 & 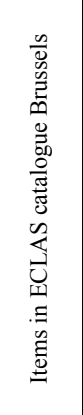 & 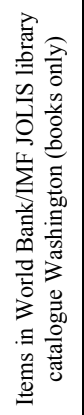 & 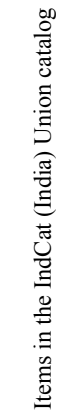 \\
\hline $\begin{array}{l}\text { (UCB) Univer- } \\
\text { sity of British } \\
\text { Columbia Press }\end{array}$ & 3.9 & 121 & 1 & 22 & 17 & 1,206 & 171 & 9 & 1 & 0 & 6 & 43 \\
\hline Anthem Press & 0.8 & 44 & 1 & 23 & 19 & 108 & 18 & 2 & 6 & 27 & 42 & 130 \\
\hline ASM Press & 2.0 & 87 & 5 & 19 & 6 & 26 & 20 & 0 & 0 & 2 & 2 & 462 \\
\hline $\begin{array}{l}\text { Ateneo de Ma- } \\
\text { nila University }\end{array}$ & 1.0 & 37 & 3 & 19 & 0 & 228 & 12 & 15 & 1,345 & 1 & 7 & 5 \\
\hline Brill & 1.4 & 215 & 28 & 32 & 23 & 8,356 & 853 & 508 & 3,311 & 118 & 99 & 3,913 \\
\hline CABI & 3.2 & 58 & 7 & 30 & 20 & 324 & 40 & 60 & 116 & 84 & 74 & 172 \\
\hline $\begin{array}{l}\text { Cambridge } \\
\text { University Press }\end{array}$ & 6.8 & 415 & 143 & 49 & 32 & 39,523 & 2875 & 699 & 198 & 2,046 & 1,944 & 75,374 \\
\hline Catena Verlag & 0.0 & 20 & 0 & 29 & 1 & 939 & 52 & 16 & 193 & 1 & 0 & 1 \\
\hline $\begin{array}{l}\text { Channel View } \\
\text { Publications }\end{array}$ & 3.0 & 56 & 0 & 30 & 8 & 21 & 3 & 0 & 0 & 0 & 1 & 6 \\
\hline CRC Press & 6.8 & 456 & 29 & 36 & 11 & 800 & 89 & 32 & 27 & 218 & 84 & 6,707 \\
\hline De Gruyter & 2.9 & 187 & 76 & 46 & 22 & 7,040 & 221 & 26 & 3 & 395 & 49 & 1,879 \\
\hline $\begin{array}{l}\text { Duke University } \\
\text { Press }\end{array}$ & 0.0 & 137 & 32 & 31 & 12 & 12,734 & 948 & 153 & 30 & 34 & 71 & 1,264 \\
\hline $\begin{array}{l}\text { Earthscan Pub- } \\
\text { lications Ltd. }\end{array}$ & 1.3 & 80 & 0 & 24 & 7 & 413 & 17 & 8 & 0 & 7 & 95 & 633 \\
\hline $\begin{array}{l}\text { Edinburgh } \\
\text { University Press }\end{array}$ & 1.4 & 99 & 24 & 32 & 21 & 4,852 & 111 & 24 & 16 & 43 & 22 & 1,462 \\
\hline Edward Elgar & 2.4 & 120 & 51 & 21 & 11 & 2,863 & 278 & 125 & 771 & 1,284 & 1,448 & 3,844 \\
\hline Elsevier & 8.4 & 369 & 79 & 36 & 30 & 6,151 & 422 & 1,359 & 1,733 & 1,109 & 335 & 24,199 \\
\hline IEEE & 0.0 & 204 & 21 & 27 & 21 & 1,553 & 263 & 525 & 232 & 48 & 5 & 2,004 \\
\hline Ios Press & 1.4 & 66 & 5 & 30 & 22 & 245 & 9 & 14 & 0 & 89 & 31 & 148 \\
\hline Island Press & 1.0 & 53 & 8 & 23 & 20 & 1,369 & 161 & 103 & 51 & 87 & 101 & 182 \\
\hline IWA Publishing & 2.9 & 14 & 0 & 20 & 3 & 3 & 1 & 0 & 0 & 22 & 32 & 12 \\
\hline John Benjamins & 3.5 & 162 & 34 & 25 & 21 & 1,498 & 47 & 6 & 0 & 91 & 1 & 1,562 \\
\hline \begin{tabular}{l|} 
Johns Hopkins \\
University Press
\end{tabular} & 2.3 & 152 & 40 & 34 & 21 & 19,506 & 607 & 229 & 73 & 130 & 323 & 2,344 \\
\hline Karger & 2.4 & 92 & 15 & 33 & 14 & 1,025 & 79 & 34 & 174 & 11 & 3 & 2,171 \\
\hline $\begin{array}{l}\text { Kluwer } \\
\text { Academic } \\
\text { Publishers }\end{array}$ & 22.0 & 162 & 51 & 34 & 19 & 6,872 & 245 & 416 & 122 & 3,047 & 1,352 & 6,508 \\
\hline
\end{tabular}




\begin{tabular}{|c|c|c|c|c|c|c|c|c|c|c|c|c|}
\hline Publisher & 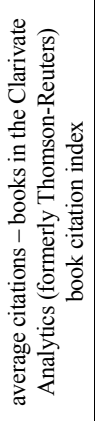 & 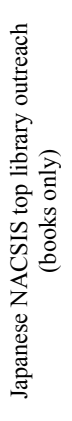 & 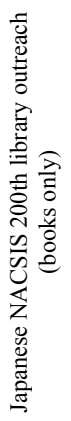 & 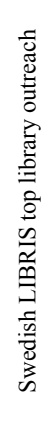 & 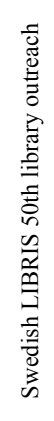 & 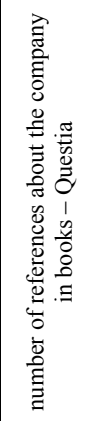 & 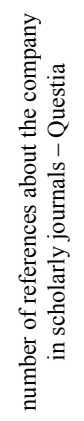 & 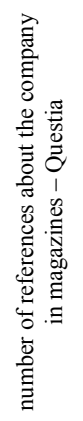 & 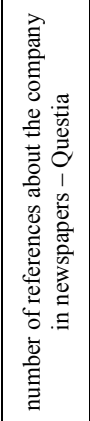 & 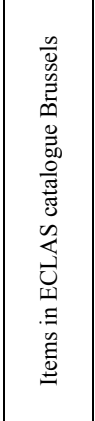 & 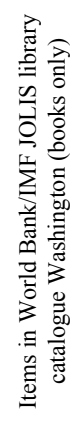 & 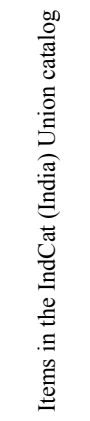 \\
\hline L'Harmattan & 0.0 & 40 & 11 & 20 & 3 & 1,460 & 70 & 2 & 1 & 1205 & 103 & 0 \\
\hline MIT Press & 8.7 & 297 & 94 & 36 & 23 & 18,155 & 711 & 330 & 63 & 443 & 653 & 5,500 \\
\hline \begin{tabular}{|l|} 
Nottingham \\
University Press \\
\end{tabular} & 0.8 & 5 & 0 & 28 & 1 & 20 & 2 & 1 & 1 & 3 & 1 & 2 \\
\hline $\begin{array}{l}\text { Nova Science } \\
\text { Publishers }\end{array}$ & 0.6 & 36 & 5 & 23 & 22 & 206 & 16 & 4 & 1 & 17 & 202 & 132 \\
\hline \begin{tabular}{|l|} 
Oxford \\
University Press
\end{tabular} & 11.0 & 399 & 155 & 55 & 33 & 50,233 & 3,523 & 1,710 & 894 & 3,358 & 4,817 & $\begin{array}{c}143,67 \\
0\end{array}$ \\
\hline $\begin{array}{l}\text { Palgrave } \\
\text { Macmillan }\end{array}$ & 2.5 & 172 & 33 & 32 & 20 & 3,632 & 1076 & 308 & 157 & 1,146 & 1,163 & 2,513 \\
\hline \begin{tabular}{|l|} 
Praxis \\
Publishing Ltd. \\
\end{tabular} & 1.7 & 27 & 1 & 19 & 7 & 11 & 0 & 0 & 0 & 7 & 3 & 16 \\
\hline \begin{tabular}{|l|} 
Princeton \\
University Press \\
\end{tabular} & 18.5 & 219 & 79 & 31 & 22 & 32,770 & 1,007 & 522 & 147 & 266 & 481 & 13972 \\
\hline Rodopi & 2.3 & 63 & 13 & 23 & 22 & 2,127 & 310 & 20 & 6 & 50 & 0 & 135 \\
\hline Routledge & 4.1 & 252 & 106 & 55 & 31 & 35,862 & 2,431 & 862 & 7,616 & 2,420 & 1,906 & 78,188 \\
\hline $\begin{array}{l}\text { Royal Society of } \\
\text { Chemistry }\end{array}$ & 15.1 & 144 & 9 & 29 & 20 & 92 & 18 & 83 & 238 & 70 & 6 & 1,477 \\
\hline Springer & 4.2 & 228 & 117 & 40 & 36 & 11,272 & 1,241 & 1,177 & 13,917 & 30,655 & 1,819 & 64,801 \\
\hline Studium Press & 0.2 & 1 & 0 & 46 & 0 & 0 & 0 & 0 & 0 & 3 & 0 & 15 \\
\hline \begin{tabular}{|l|} 
Trans Tech \\
Publications
\end{tabular} & 0.3 & 32 & 3 & 19 & 15 & 0 & 0 & 1 & 0 & 0 & 0 & 142 \\
\hline \begin{tabular}{|l|} 
Transaction \\
Publishing
\end{tabular} & 1.0 & 56 & 17 & 34 & 13 & 2,373 & 116 & 51 & 13 & 46 & 111 & 309 \\
\hline $\begin{array}{l}\text { Universidad } \\
\text { Nacional } \\
\text { Autonoma } \\
\text { de Mexico }\end{array}$ & 0.0 & 17 & 2 & 29 & 2 & 709 & 24 & 115 & 14 & 6 & 40 & 47 \\
\hline \begin{tabular}{|l|}
$\begin{array}{l}\text { University of } \\
\text { California Press }\end{array}$ \\
\end{tabular} & 6.9 & 155 & 63 & 33 & 23 & 31,182 & 1,066 & 412 & 142 & 93 & 137 & 7,332 \\
\hline \begin{tabular}{|l} 
University of \\
Chicago Press
\end{tabular} & 2.1 & 264 & 76 & 39 & 22 & 36,180 & 1,255 & 433 & 153 & 149 & 344 & 12,653 \\
\hline $\begin{array}{l}\text { University of } \\
\text { Illinois Press }\end{array}$ & 3.1 & 149 & 31 & 36 & 21 & 13,980 & 781 & 132 & 42 & 6 & 13 & 905 \\
\hline $\begin{array}{l}\text { University of } \\
\text { New Mexico } \\
\text { Press }\end{array}$ & 0.0 & 94 & 5 & 22 & 20 & 3,934 & 149 & 37 & 13 & 0 & 2 & 143 \\
\hline
\end{tabular}


Tausch • The Market Power of Global Scientific Publishing Companies

\begin{tabular}{|c|c|c|c|c|c|c|c|c|c|c|c|c|}
\hline Publisher & 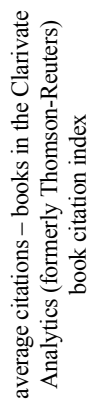 & 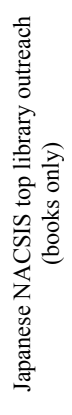 & 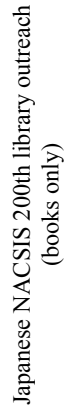 & 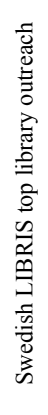 & 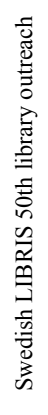 & 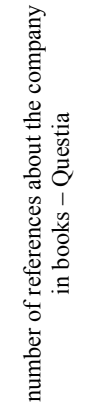 & 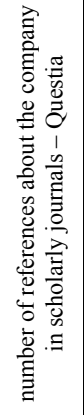 & 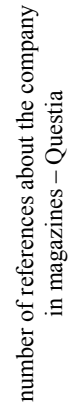 & 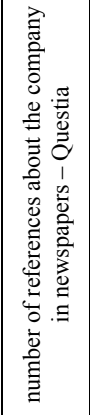 & 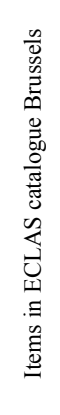 & 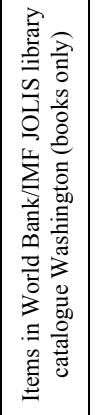 & 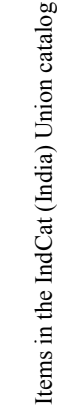 \\
\hline $\begin{array}{l}\text { University of } \\
\text { North Carolina } \\
\text { Press }\end{array}$ & 7.1 & 130 & 27 & 36 & 21 & 14,362 & 930 & 113 & 58 & 3 & 14 & 1092 \\
\hline $\begin{array}{l}\text { University of } \\
\text { Pennsylvania } \\
\text { Press }\end{array}$ & 5.8 & 112 & 24 & 32 & 18 & 11,268 & 482 & 50 & 18 & 12 & 68 & 848 \\
\hline Wageningen & 1.7 & 15 & 0 & 30 & 8 & 558 & 19 & 52 & 127 & 158 & 71 & 59 \\
\hline $\begin{array}{l}\text { Wiley- } \\
\text { Blackwell }\end{array}$ & 1.9 & 105 & 20 & 38 & 29 & 761 & 230 & 78 & 11 & 39 & 41 & 144 \\
\hline $\begin{array}{l}\text { Wilfrid Laurier } \\
\text { University Press }\end{array}$ & 2.4 & 35 & 1 & 26 & 20 & 21 & 0 & 0 & 0 & 4 & 4 & 31 \\
\hline WIT Press & 3.1 & 20 & 1 & 5 & 1 & 9 & 11 & 0 & 0 & 15 & 9 & 22 \\
\hline $\begin{array}{l}\text { Woodhead } \\
\text { Publishing }\end{array}$ & 2.7 & 24 & 1 & 26 & 7 & 17 & 0 & 3 & 2 & 15 & 3 & 237 \\
\hline World Bank & 8.6 & 165 & 32 & 34 & 22 & 10,050 & 4,231 & 7,448 & 12,498 & 691 & 16,600 & 19,902 \\
\hline $\begin{array}{l}\text { World } \\
\text { Scientific and } \\
\text { Engineering } \\
\end{array}$ & 2.0 & 1 & 0 & 30 & 20 & 4 & 0 & 5 & 0 & 0 & 0 & 0 \\
\hline $\begin{array}{l}\text { Yale University } \\
\text { Press }\end{array}$ & 0.0 & 141 & 54 & 32 & 20 & 31,640 & 1,024 & 673 & 412 & 140 & 145 & 6,471 \\
\hline
\end{tabular}




\begin{tabular}{|c|c|c|c|c|c|c|}
\hline Publisher & \begin{tabular}{|l|} 
total num- \\
ber of re- \\
cent titles
\end{tabular} & $\begin{array}{l}\text { Recent ti- } \\
\text { tles with } \\
\text { more than } \\
50 \text { circula- } \\
\text { tion }\end{array}$ & $\begin{array}{l}\text { Recent ti- } \\
\text { tles with } \\
\text { more than } \\
500 \text { circu- } \\
\text { lation }\end{array}$ & $\begin{array}{l}\% \text { of titles } \\
\text { with a cir- } \\
\text { culation of } \\
\text { more than } \\
500\end{array}$ & $\begin{array}{l}\% \text { of titles } \\
\text { with a circu- } \\
\text { lation be- } \\
\text { tween } 50 \text { and } \\
500\end{array}$ & $\begin{array}{l}\% \text { of titles } \\
\text { with a cir- } \\
\text { culation of } \\
\text { less than } 50\end{array}$ \\
\hline $\begin{array}{l}\text { (UCB) University of } \\
\text { British Columbia } \\
\text { Press }\end{array}$ & 132 & 5 & 0 & 0.000 & 3.788 & 96.212 \\
\hline Anthem Press & 2,000 & 282 & 97 & 4.850 & 9.250 & 85.900 \\
\hline ASM Press & 555 & 79 & 27 & 4.865 & 9.369 & 85.766 \\
\hline $\begin{array}{l}\text { Ateneo de Manila } \\
\text { University }\end{array}$ & 242 & 2 & 0 & 0.000 & 0.826 & 99.174 \\
\hline Brill & 46,977 & 3,965 & 1072 & 2.282 & 6.158 & 91.560 \\
\hline CABI & 2,857 & 160 & 0 & 0.000 & 5.600 & 94.400 \\
\hline $\begin{array}{l}\text { Cambridge } \\
\text { University Press }\end{array}$ & 111,263 & 10,244 & 38 & 0.034 & 9.173 & 90.793 \\
\hline Catena Verlag & 162 & 0 & 0 & 0.000 & 0.000 & 100.000 \\
\hline $\begin{array}{l}\text { Channel View } \\
\text { Publications } \\
\end{array}$ & 812 & 83 & 6 & 0.739 & 9.483 & 89.778 \\
\hline CRC Press & 64,787 & 6,427 & 5 & 0.008 & 9.912 & 90.080 \\
\hline De Gruyter & 80,805 & 3,541 & 660 & 0.817 & 3.565 & 95.618 \\
\hline $\begin{array}{l}\text { Duke University } \\
\text { Press }\end{array}$ & 6,091 & 1,253 & 6 & 0.099 & 20.473 & 79.429 \\
\hline $\begin{array}{l}\text { Earthscan } \\
\text { Publications Ltd. }\end{array}$ & 1,261 & 117 & 0 & 0.000 & 9.278 & 90.722 \\
\hline $\begin{array}{l}\text { Edinburgh University } \\
\text { Press }\end{array}$ & 8,739 & 1,358 & 284 & 3.250 & 12.290 & 84.460 \\
\hline Edward Elgar & 20,276 & 1,259 & 1 & 0.005 & 6.204 & 93.791 \\
\hline Elsevier & 171,050 & 7,536 & 164 & 0.096 & 4.310 & 95.594 \\
\hline Equinox & 1,367 & 140 & 1 & 0.073 & 10.168 & 89.759 \\
\hline IEEE & 56,003 & 8,212 & 7 & 0.012 & 14.651 & 85.336 \\
\hline Ios Press & 3,227 & 306 & 155 & 4.803 & 4.679 & 90.518 \\
\hline Island Press & 2,164 & 265 & 90 & 4.159 & 8.087 & 87.754 \\
\hline IWA Publishing & 1,757 & 164 & 27 & 1.537 & 7.797 & 90.666 \\
\hline John Benjamins & 7,488 & 882 & 404 & 5.395 & 6.384 & 88.221 \\
\hline $\begin{array}{l}\text { Johns Hopkins } \\
\text { University Press }\end{array}$ & 4,726 & 1,009 & 255 & 5.396 & 15.954 & 78.650 \\
\hline Karger & 4,486 & 165 & 0 & 0.000 & 3.678 & 96.322 \\
\hline $\begin{array}{l}\text { Kluwer Academic } \\
\text { Publishers }\end{array}$ & 42,480 & 1,395 & 146 & 0.344 & 2.940 & 96.716 \\
\hline L'Harmattan & 51,237 & 141 & 0 & 0.000 & 0.275 & 99.725 \\
\hline MIT Press & 13,120 & 1,942 & 421 & 3.209 & 11.593 & 85.198 \\
\hline $\begin{array}{l}\text { Nottingham Univer- } \\
\text { sity Press }\end{array}$ & 6 & 0 & 0 & 0.000 & 0.000 & 100.000 \\
\hline $\begin{array}{l}\text { Nova Science } \\
\text { Publishers }\end{array}$ & 16,921 & 2,168 & 998 & 5.898 & 6.914 & 87.188 \\
\hline Palgrave Macmillan & 118,716 & 16,767 & 85 & 0.072 & 14.052 & 85.876 \\
\hline Praxis Publishing Ltd. & 1,191 & 44 & 0 & 0.000 & 3.694 & 96.306 \\
\hline
\end{tabular}


Tausch • The Market Power of Global Scientific Publishing Companies

\begin{tabular}{|c|c|c|c|c|c|c|}
\hline Publisher & $\begin{array}{l}\text { total num- } \\
\text { ber of re- } \\
\text { cent titles }\end{array}$ & $\begin{array}{l}\text { Recent ti- } \\
\text { tles with } \\
\text { more than } \\
50 \text { circula- } \\
\text { tion }\end{array}$ & $\begin{array}{l}\text { Recent ti- } \\
\text { tles with } \\
\text { more than } \\
500 \text { circu- } \\
\text { lation }\end{array}$ & $\begin{array}{l}\% \text { of titles } \\
\text { with a cir- } \\
\text { culation of } \\
\text { more than } \\
500\end{array}$ & $\begin{array}{c}\% \text { of titles } \\
\text { with a circu- } \\
\text { lation be- } \\
\text { tween } 50 \text { and } \\
500 \\
\end{array}$ & $\begin{array}{l}\% \text { of titles } \\
\text { with a cir- } \\
\text { culation of } \\
\text { less than } 50\end{array}$ \\
\hline $\begin{array}{l}\text { Princeton University } \\
\text { Press }\end{array}$ & 23,198 & 3,217 & 863 & 3.720 & 10.147 & 86.132 \\
\hline $\begin{array}{l}\text { Resources for the Fu- } \\
\text { ture }\end{array}$ & 40 & 1 & 0 & 0.000 & 2.500 & 97.500 \\
\hline Rodopi & 4,242 & 512 & 174 & 4.102 & 7.968 & 87.930 \\
\hline Routledge & 296,550 & 18,376 & 228 & 0.077 & 6.120 & 93.803 \\
\hline $\begin{array}{l}\text { Royal Society of } \\
\text { Chemistry }\end{array}$ & 9,094 & 435 & 164 & 1.803 & 2.980 & 95.217 \\
\hline Springer & 573,931 & 44,928 & 423 & 0.074 & 7.754 & 92.172 \\
\hline Studium Press & 83 & 0 & 0 & 0.000 & 0.000 & 100.000 \\
\hline \begin{tabular}{|l|} 
Trans Tech Publica- \\
tions
\end{tabular} & 6,774 & 819 & 513 & 7.573 & 4.517 & 87.910 \\
\hline $\begin{array}{l}\text { Transaction Publi- } \\
\text { shing }\end{array}$ & 2,244 & 285 & 0 & 0.000 & 12.701 & 87.299 \\
\hline $\begin{array}{l}\text { Universidad Nacional } \\
\text { Autonoma de Mexico }\end{array}$ & 5,677 & 38 & 0 & 0.000 & 0.669 & 99.331 \\
\hline $\begin{array}{l}\text { University of Cali- } \\
\text { fornia Press }\end{array}$ & 8,941 & 1,758 & 432 & 4.832 & 14.831 & 80.338 \\
\hline $\begin{array}{l}\text { University of Chica- } \\
\text { go Press }\end{array}$ & 13,052 & 2,786 & 89 & 0.682 & 20.663 & 78.655 \\
\hline $\begin{array}{l}\text { University of Illinois } \\
\text { Press }\end{array}$ & 5,422 & 1,340 & 467 & 8.613 & 16.101 & 75.286 \\
\hline $\begin{array}{l}\text { University of New } \\
\text { Mexico Press }\end{array}$ & 1,548 & 462 & 60 & 3.876 & 25.969 & 70.155 \\
\hline $\begin{array}{l}\text { University of North } \\
\text { Carolina Press }\end{array}$ & 4,132 & 1,067 & 247 & 5.978 & 19.845 & 74.177 \\
\hline $\begin{array}{l}\text { University of Penn- } \\
\text { sylvania Press }\end{array}$ & 7,894 & 1,445 & 66 & 0.836 & 17.469 & 81.695 \\
\hline \begin{tabular}{|l|} 
University of \\
Washington Press
\end{tabular} & 2,612 & 565 & 146 & 5.590 & 16.041 & 78.369 \\
\hline \begin{tabular}{|l|} 
Wageningen \\
\end{tabular} & 10,592 & 17 & 0 & 0.000 & 0.160 & 99.840 \\
\hline Wiley-Blackwell & 34,596 & 2,640 & 135 & 0.390 & 7.241 & 92.369 \\
\hline \begin{tabular}{|l} 
Wilfrid Laurier Uni- \\
versity Press \\
\end{tabular} & 1,111 & 242 & 28 & 2.520 & 19.262 & 78.218 \\
\hline WIT Press & 1,303 & 12 & 0 & 0.000 & 0.921 & 99.079 \\
\hline $\begin{array}{l}\text { Woodhead } \\
\text { Publishing }\end{array}$ & 4,339 & 643 & 31 & 0.714 & 14.105 & 85.181 \\
\hline World Bank & 13,304 & 695 & 0 & 0.000 & 5.224 & 94.776 \\
\hline \begin{tabular}{|l|} 
World Scientific \\
\end{tabular} & 22,151 & 1,376 & 634 & 2.862 & 3.350 & 93.788 \\
\hline Yale University Press & 13,434 & 2,524 & 300 & 2.233 & 16.555 & 81.212 \\
\hline
\end{tabular}

